Article

\title{
Strikes and Rural Unrest during the Second Spanish Republic (1931-1936): A Geographic Approach
}

\author{
Javier Puche ${ }^{1, * \mathbb{D}}$ and Carmen González Martínez ${ }^{2}$ \\ 1 Faculty of Social and Human Sciences, University of Zaragoza, Ciudad Escolar s/n, 44003 Teruel, Spain \\ 2 Faculty of Letters, University of Murcia, Campus de la Merced, 30071 Murcia, Spain; cargonza@um.es \\ * Correspondence: jpuche@unizar.es; Tel.: +34-978-645-337
}

Received: 27 October 2018; Accepted: 17 December 2018; Published: 21 December 2018

\begin{abstract}
This article analyses the evolution and geographic distribution of the rural unrest that prevailed during the years of the Second Spanish Republic (1931-1936), a period characterised by political instability and social conflict. The number of provincial strikes recorded in the forestry and agricultural industries and complied by the Ministry of Labour and Social Welfare constitute the primary source of the study. Based on this information, maps of the regional and provincial distribution of the agricultural unrest have been created for the republican period. The results reveal that, contrary to the traditional belief which confines the rural unrest of this period to the geographic areas of the latifundios (large estates), Spanish agriculture, in all its diversity, was hit by collective disputes. Although the areas of the latifundios were most affected by the agricultural reform of 1932, the data show that the extension of the unrest in the Spanish countryside was also the result of the refusal of the landowners to accept and apply the new republican collective bargaining agreement. The number of strikes increased during the period 1931-1933, fell between 1934 and 1935, and increased again during the months of the Popular Front (February to July 1936).
\end{abstract}

Keywords: Second Spanish Republic; countryside; labour unrest; strikes; agricultural reform; collective bargaining

\section{Introduction}

The interwar period that constitutes the timeframe of this article is still highly attractive to historians and political scientists throughout the world. The consequences of the First World War in Europe triggered a widespread crisis in European liberalism and the rise of authoritarian, totalitarian, and nationalist political and social movements in a period which, according to George Mosse was characterised by the "brutalisation of politics" [1,2]; and, until 1939 was accompanied by a growing "paramilitarisation of politics", particularly among the younger members of the political organisations [3]. The strength of the left-wing parties and trade unions, and their capacity to mobilise many rural and city workers faltered in the face of the corporativist discourses used by employer organisations and the progressive discontent of broad segments of the middle classes, reflecting the increasing political fragmentation existing in European society [4,5]. The Spanish experience was no exception in the European context. It ran in parallel with the breakdown of the liberal system after the First World War, and the boom in ideological radicalism and political violence between 1914 and 1945 [6].

Following the compromise solution of the dictatorship of Primo de Rivera (1923-1930), the arrival of the democratic regime of the Second Republic in 1931 constituted an attempt to reform the political, economic and social structures of the country. Never in the history of Spain had there been such an intense and accelerated period of change, democratic advances and social achievements, but it was not exempt from conflict. During the first two years of the Republic, the armed forces were restructured, the Church was separated from the State and far-reaching measures were taken with respect to the 
distribution of land ownership, working conditions, employment protection and public education [7]. These reforms generated their respective conflicts and opposition among the traditional groups of power which rejected them.

The change of regime also coincided with the international economic crisis of the 1930s, characterised by a period of low overall economic activity, mass unemployment and deflation [8]. In addition, the union organisations became more powerful (anarchic and, most of all, socialist), and new labour laws were passed which sought to improve the living and working conditions of urban and rural workers [9]. However, this republican legislation brought to the forefront some of the tension emerging during the two preceding decades with industrialisation, urbanisation and class conflicts. The Republic found it difficult to consolidate and develop its reformist project [10]. The situation of labour relations in the countryside illustrates this, particularly with respect to everything surrounding the agricultural reform of 1932 and the labour legislation which was received with widespread rural unrest [11-18]. The Republic was characterised by a reformist spirit which, in some spheres such as the countryside, which until then were unmovable and controlled by the agricultural employers, began to adopt a revolutionary stance.

It should be taken into account that the reforms had a considerable impact, as almost $50 \%$ of the active population in the 1930s worked in the agricultural sector. On the one hand, because a series of decrees were passed aimed at resolving the problem of unemployment, such as obliging landowners to hire day labourers from the same town, to distribute labour among farms and to farm their land following the "traditional land uses", in order to increase employment. On the other hand, due to the implementation of collective bargaining to establish working conditions by law, which gave rise to the rapid expansion of workers organisations and obliged the employers to create their respective employers organisations. And, finally, the passing of an agricultural reform in 1932 which, seeking to put an end to the predominance of latifundismo (large-scale landholding) existing in a good part of central and southern Spain, generated one of the most important opposition movements to the republican reformism.

The results of the agricultural reform were limited due to the slow pace of its application, the lack of funds and, most of all, the resistance by landowners, who saw it as an infringement of the principle of ownership [16,17]. This opposition gave rise to a considerable increase in social tension, principally where there was a predominance of latifundios, which caused a part of the historiography of the 1970s and 1980s to focus exclusively on the unrest in the areas where latifundismo was predominant, underestimating the extension of the collective conflicts in other Spanish agricultural contexts [19-21].

More recently, the historiographic debate has revolved around the determining factors of the Republican rural conflict $[14,15,18,22,23]$. Along with the hypotheses that emphasise the dominance of political factors in the generation of social unrest during the Second Republic [24-27], studies carried out over the last two decades focus on the economic factors and the formulation of new labour relations as determining elements of the rural unrest $[14,15,28,29]$. Based on this line of research, this article contributes to the study of the rural unrest during the Second Republic based on the analysis of the number of strikes classified by provinces in the forestry and agricultural industries. To do that, the historical geography approach is adopted as a method of study to analyse the distribution of agrarian conflicts through the different political stages that the republican regime went through. It is a methodology that, based on the territorial use of strike data, allows us to measure the incidence that rural policies and labour relations had in the different Spanish regions and provinces of that time. Although the reality in the Spanish countryside was more complex, and the strikes and rural conflict more numerous than the sources indicate, this study provides evidence of the evolution and geographic distribution of the rural unrest during the period 1931-1936 for the whole of the Spanish territory in the different agricultural contexts of the country, not only the areas where latifundismo was predominant.

The results reveal that, contrary to the traditional belief that confines the rural unrest of this period to the geographic areas of the latifundios (large estates), Spanish agriculture, in all its diversity, 
was hit by many collective disputes. And although the areas where latifundismo was predominant were most affected by the agricultural reform of 1932, the data show that the spread of unrest in the Spanish countryside was also the result of the confluence of different factors, for example, the economic crisis that, for different reasons, affected the exporting sectors of Spanish agriculture and the traditional Castilian cereal agriculture and, more immediately, the refusal of the landowners to accept the working conditions approved in collective bargaining. The results also show that the evolution of the agricultural strikes was subject to cycles conditioned by factors of political, economic and labour policy conjuncture; so the strikes increased during the first two years of the Republic, particularly in 1933. They decreased in 1934-1935 and increased again during the months of the Popular Front (February to June 1936).

The article is structured into four sections; the first is this introduction, which presents the objective of the study; the second describes the sources of the study and the methodology used; the third presents the results obtained and the historiographic discussion; and the fourth summarises the final conclusions.

\section{Materials and Methods}

In order to analyse the evolution and geographic distribution of the rural unrest during the years of the Second Republic, this study has used the statistics relating to strikes compiled in the Boletines del Ministerio de Trabajo y Previsión Social (Official Gazettes of the Ministry of Employment and Social Welfare) between 1932 and July 1936. Specifically, the strikes were classified by province and the forestry or agricultural industries. This historical source is available in the Central Library of Spain's Ministry of Labour, specialised in social and labour issues. These gazettes provided monthly information about the number of strikes that the Statistics Office of the Ministry was aware of. Subsequently, the information was refined with more detailed statistics on strikes which included the number of strikers, lost workdays, causes of the strikes, etc., and which did not appear in the aforementioned gazettes until two years later. For example, the statistics of 1932 appeared in the issue of January 1934, those of 1933 in July 1935, and those of 1934 in August 1936. These statistics, classified by province and industry, were those that were summarised and published in the Anuario Estadístico (Statistical yearbook). However, for 1935 and 1936, there are only data available from the monthly gazettes (until July in the latter year), without the subsequent refinement. For all of the years of the study, except for 1931, the strike data included in the group of industries named "forestry and agriculture" are used, and which, on the whole, encompass all industries related to agriculture.

On the other hand, the data used refers to the strikes with complete information and not to the number of strikes declared. This is because we have observed that for the years 1931 and 1932, the number of strikes declared was much higher than the number of strikes with complete information, which could reflect an excessive wave of strikes during these two years. So, in 1931, the number of strikes declared was 734, while the number of strikes with complete data was 610. In 1932, the gap widened, as the number of strikes declared was 681 , while the number of strikes with complete data was 435. During the years 1933 and 1934, however, the difference between declared strikes and strikes with complete information reduced. For this reason, using the number of strikes with complete data, we can gain an insight of the strike scenario which, although on a smaller scale, should be closer to the reality of the whole of the national territory during the republican period.

The Ministry of Employment and Social Welfare Gazettes with the classification of the strikes by type of industry have not been found. We have used the statistics from the Statistical Yearbook, which does not disaggregate the data by economic sector. In order to resolve this problem, we have made an agricultural strike estimate based on the percentage weight of the agricultural workers in each of the Spanish regions and provinces, the data for which has been drawn from the study by Alcaide ([30], p. 192-193). To do so, first, the percentage that the salaried workers in the agricultural sector represented was based on total salaried employment for each of Spain's regions and provinces. This percentage has been estimated for 1930, as Alcaide's study does not provide data of salaried 
employment by sector for 1931, but on a five-yearly basis $(1930,1935,1940, \ldots$ ). Second, we have applied this percentage to the number of strikes with complete data for the year 1931 drawn from the Anuario Estadístico (Statistical Yearbook) using the following formula:

$=$ (percentage of salaried workers in the agricultural sector on a regional and provincial level in $1930 *$ number of strikes with complete data on a regional and provincial level in 1931)/100

Example: In 1930, the percentage that salaried employment represented in the agricultural sector in Andalusia was 47\%. In 1931, the number of strikes with complete data in this region was 49. Using the proposed methodology, we have estimated that $47 \%$ of the 49 strikes held in this Spanish region took place in the agricultural sector. We have done the same on a provincial level. And we have applied this calculation to all of the Spanish regions and provinces for the year 1931. We acknowledge that this estimate has some limitations: principally, as already partly explained above, for the year 1931 we have used the percentage of the salaried workers of the agricultural sector corresponding to 1930, and not 1931. Therefore, the agricultural strike data obtained for this year should be considered as an approximate estimate of the real strike situation in the Spanish countryside in the first year of the Republican regime.

Despite being the only sources available for the period on a national level, the strike data drawn from the Boletines and the Anuarios Estadísticos have some limitations. First, and as already mentioned, both sources only include the strikes and lockouts of which the Statistical Department of the Ministry was aware. Taking into account that the strike movement intensified during the republican period, particularly in 1933, there were probably moments when the real number of strikes was higher than the number reported by the Ministry in its official statistics. However, we consider that these statistics, although incomplete, enable us to identify, in approximate terms, the moments of greatest and least labour unrest during the year of the Second Spanish Republic. Second, we do not know the criterion (or criteria) established by the Ministry of Labour to consider a labour protest as a strike. However, the consultation of the Boletines of 1932-July 1936, as shown in Figure A1 of Appendix A, reveals that most of the causes that produced the strikes were related to workers' demands for better conditions (salary, working day, general working conditions, staff and association). In this sense, and without denying the possible existence of lockouts, we consider that the majority of the strikes of which the Ministry had knowledge correspond to collective interruptions of the labour activity by the workers in order to claim certain conditions or labour improvements. Third, and as previously mentioned, the strike data that we have used in this study correspond to the "forestry and agricultural" industries. Although many of the strikes and strikers must have been concentrated in rural areas (less than 10,000 inhabitants), others must have been located in larger towns, such as the Mediterranean and Andalusian agrocities (with more than 20,000 inhabitants) where there was a strong presence of agricultural workers and agroindustry. Unfortunately, the statistics of strikes published by the Ministry of Labour do not provide information at the municipal level.

Finally, we have listed the ranges of the number of strikes which we have considered in order to estimate the three levels of agricultural unrest (low, medium and high). Although the study of Rodríguez Labandeira [31] provides information about the geographic distribution of the agricultural strikes during the three-year Bolshevik period (1919-1921), it does not explain the strike periods used. Therefore, and in the absence of studies that have contemplated it, in this article, we have used an ad hoc classification on a regional and provincial level. For the regional scale, the levels of rural unrest considered are the following (in parentheses, the range of agricultural strikes): a) low level of rural unrest (1-25 strikes); b) medium level of rural unrest (26-99 strikes); and c) high level of rural unrest (over 100 strikes). For the provincial scale, the levels of unrest considered are the following: a) low level of rural unrest (1-5 strikes); b) medium level of rural unrest (6-15 strikes); and c) high level of rural unrest (over 16 strikes). 


\section{Results and Discussion}

\subsection{Labour Unrest}

Figure 1 identifies the cycles of greatest labour unrest of the first third of the twentieth century in Spain based on the strike data for which complete data is available.

1200

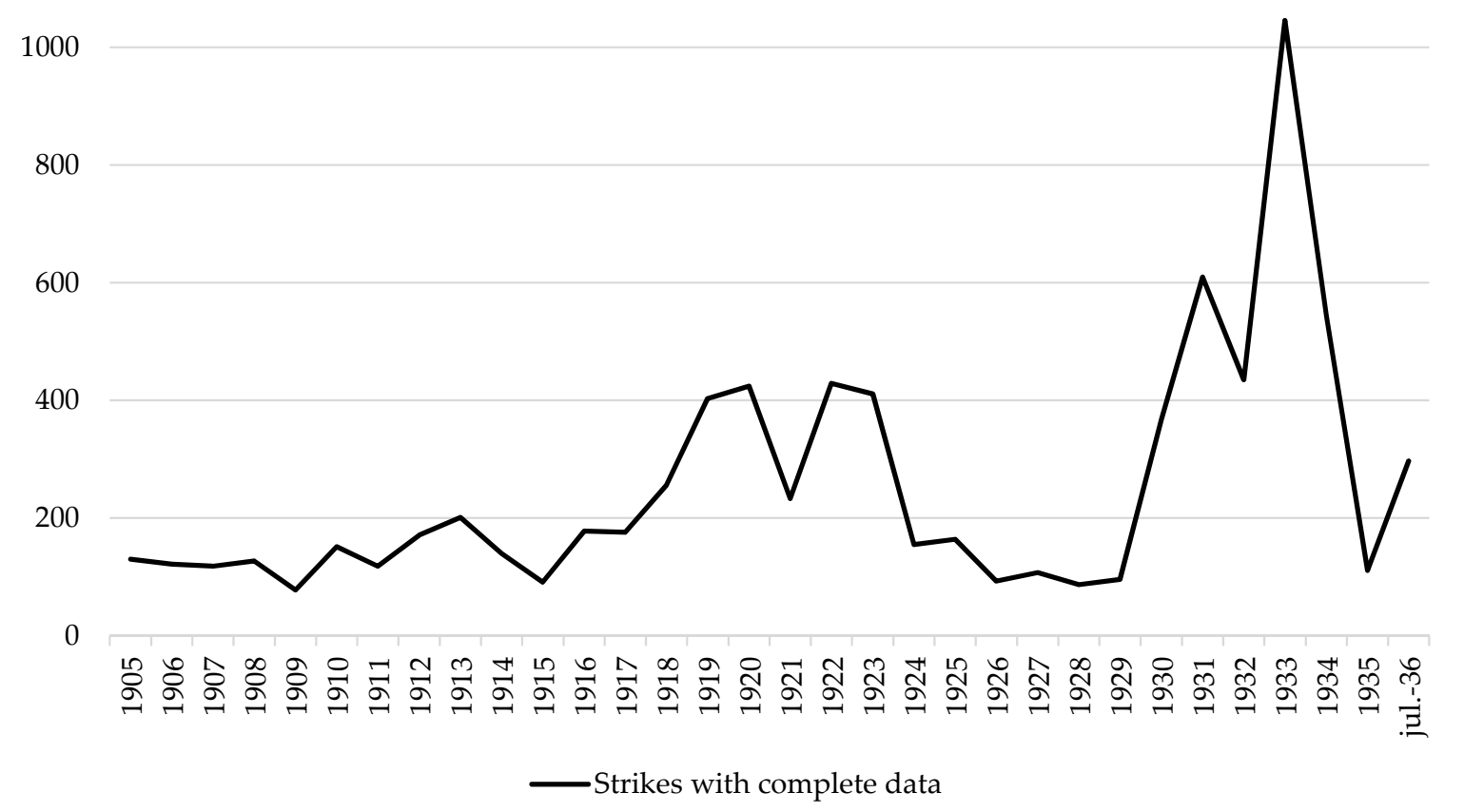

Figure 1. Strikes with complete data in Spain, 1905-July 1936. Data source: Anuarios Estadísticos de España (1930) and ([32], p. 75). Own elaboration.

According to this series, the number of strikes experienced a preliminary increase between 1910 and 1913, and increased again between 1916 and 1919. The La Canadiense strike in Barcelona during the first semester of 1919 was very important because, when it concluded, the decree that established the legal working day of eight hours in Spain was enacted. After the First World War, from 1920 to 1924 , the series reached its historical maximum level, which can be explained by the resistance of the employers to accept wage increases amidst a post-war crisis and the prolongation of conflicts. With the economic depression of 1930, and the political and social instability during the first two years of the Second Republic, the strike movement and the unrest intensified, particularly in 1933. However, both the official sources and the specialised research indicate that the upward trend in the number of strikes began before the arrival of the republican regime: they had quadrupled between 1929 and 1930, continued to rise in 1931 until almost doubling again in 1933, which was the year when the unrest peaked, at least until the spring of 1936. 1935, on the other hand, was an atypical year, probably explained by the severe political and social repression after the Revolution of October 1934. In spite of this, the period of the Second Republic is known as one of the two great cycles of unrest throughout the first third of the twentieth century [33].

Figure 2 shows that the strikes in forestry and agricultural industries evolved in a similar way to the overall number of strikes (a smaller number in the forestry industry). The strike series with which we have worked, referring to forestry and agricultural activities, confirms the increase, in real terms, of the agricultural unrest during the first two-year period. The increase reached its maximum point in 1933, when the percentage of agricultural strikes represented $41.6 \%$. From this year, we can observe a continuous decrease, which was rapid until 1935, resulting from the contraction of the rural unrest 
during the second Republican biennium (November 1933-February 1936), followed by an upturn during the spring of 1936, after the elections of February 1936 which were won by the coalition of left-wing parties of the Spanish Popular Front.

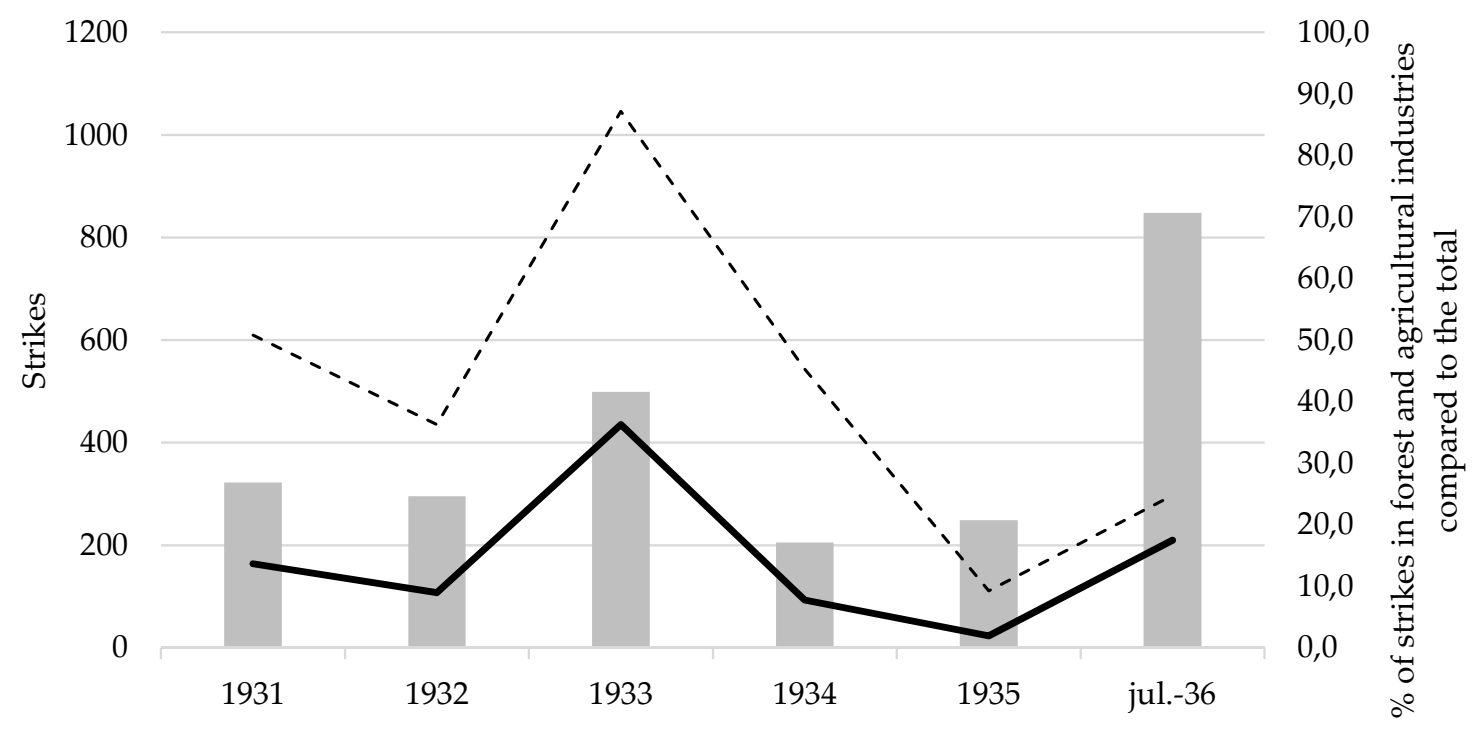

$\%$ of strikes in forest and agricultural industries compared to the total

- - - Strikes with complete data

Strikes in forestry and agrarian industries

Figure 2. Strikes in forestry and agricultural industries in Spain, 1931-July 1936. Data source: Anuario Estadístico de España (1931), ([30], p. 192-193) and Boletines del Ministerio de Trabajo y Previsión Social (1932-July 1936). Own elaboration.

Meanwhile, Table 1 shows the percentage distribution of the number of strikes, striking workers and lost days in the forestry and agricultural industries by Spanish region between 1932 and 1934 . The panel shows that, for the three indicators, Andalusia was the region with the highest number of strikes (a third of the national total), striking workers (almost $50 \%$ ) and lost days $(62.3 \%)$. These figures can be explained not only by the size of the territory, but also the level of implementation and mobilisation of the agricultural unions in the majority of the Andalusian provinces, the incidence of unemployment and the weight that agriculture still had in the regional economy. In terms of the percentage of strikes, Andalusia was followed by Castilla-León (with 24.5\%), Castilla-La Mancha $(8.7 \%)$ and the Region of Valencia $(7.8 \%)$. With respect to the percentage of striking workers, Andalusia was followed by the Region of Valencia (11.6\%), Castilla-León (8.3\%) and Extremadura (8.1\%). In this respect, the case of Asturias is noteworthy. With barely $1 \%$ in the regional distribution of the number of strikes, the striking workers accounted for $7.3 \%$, and $6.2 \%$ lost days, which is probably explained by the impact that the strike of October 1934 had on this region in the north of Spain. Finally, and with respect to lost days, Andalusia was followed, although with a considerable gap, by the Region of Valencia (with 7.8\%) and Castilla-León (6.5\%). 
Table 1. Percentage of strikes, striking workers and lost days in forestry and agricultural industries by Spanish region, 1932-1934 *.

\begin{tabular}{lccc}
\hline & Strikes & Striking Workers & Lost Days \\
\hline Andalucía & 32.5 & 49.9 & 62.3 \\
Aragón & 4.8 & 1.3 & 0.9 \\
Asturias & 0.9 & 7.3 & 6.2 \\
Baleares & 1.2 & 0.1 & 0.0 \\
Canarias & 2.9 & 2.8 & 4.2 \\
Cantabria & 0.3 & 0.0 & 0.0 \\
Castilla-La & 8.7 & 6.3 & 4.7 \\
Mancha & 24.5 & 8.3 & 6.5 \\
Castilla-León & 2.4 & 0.4 & 0.6 \\
Cataluña & 7.8 & 11.6 & 7.8 \\
Valencia & 2.8 & 8.1 & 4.2 \\
Extremadura & 3.4 & 0.1 & 0.0 \\
Galicia & 3.5 & 1.3 & 1.0 \\
Madrid & 1.5 & 1.5 & 0.7 \\
Murcia & 0.6 & 0.6 & 0.3 \\
Navarra & 0.3 & 0.0 & 0.0 \\
País Vasco & 2.0 & 0.4 & 0.3 \\
La Rioja & 100 & 100 & 100 \\
\hline Total & & & \\
\hline
\end{tabular}

* The statistical information referring to strikes, striking workers and lost days by industry is not available for the years 1931, 1935, January-July 1936. Data source: Boletines del Ministerio de Trabajo y Previsión Social (1933, 1935, 1936). Own elaboration.

\subsection{Rural Unrest on a Regional Scale}

In this section, we will trace the three classic stages of study of the Second Spanish Republic: (a) first biennium (April 1931-November 1933), governed by a centre-left coalition); (b) second biennium (November 1933-February 1936), governed by a centre-right coalition; and (c) the stage of the Popular Front (February-July 1936), governed by a coalition of the principally left-wing parties. The approach of historical geography is adopted as a method of study to analyse the distribution of agrarian conflicts through the different political stages that the republican regime went through. It is a methodology that, from the aggregation of strike data at the provincial level, allows measuring the incidence that rural policies and labour relations had in the different Spanish regions of the time.

\subsubsection{First Biennium 1931-1933}

Figures 3-5 present the results of the geographic distribution of the number of strikes in forestry and agricultural industries and their intensity, by Spanish region, in the years 1931, 1932 and 1933. The data reveal, on the one hand, contrasts in the regional distribution of the strikes in the first biennium of the republic and, on the other, a progressive increase of the rural unrest, recording a greater intensity in 1933. In general, the maps show that the rural unrest of the first biennium - which the cliché reduces to the geographical area of the latifundios-was more diverse and rich in nuances, consistent with the complexity of the historical period, and which was generated not only by the impact of the early announcement of the agricultural reform but also by political and economic factors and labour laws. 


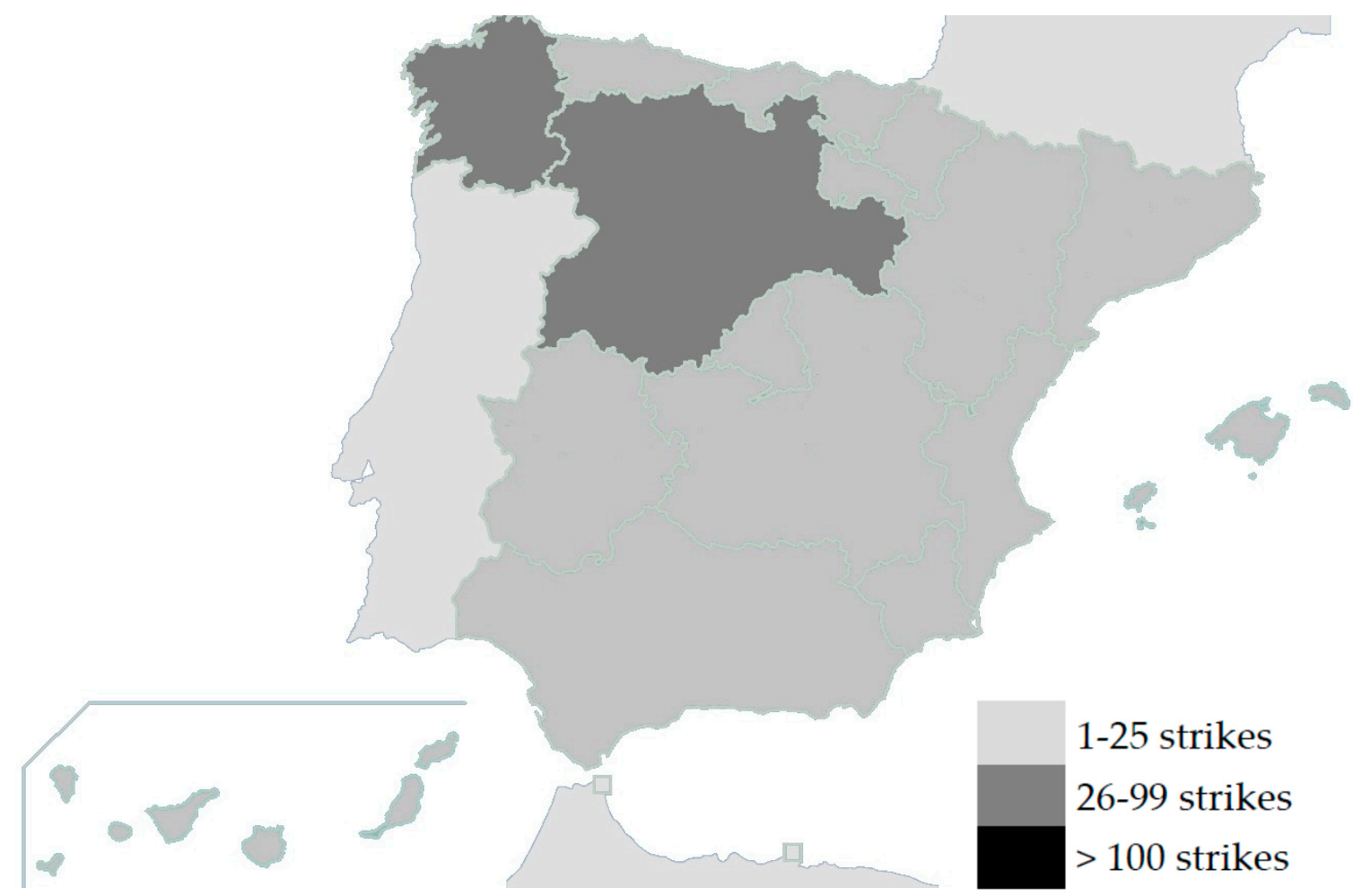

Figure 3. Geographic distribution of the strikes in forestry and agricultural industries by Spanish region, 1931. Data source: Anuario Estadístico de España (1931) and ([30], p. 192-193). Own elaboration.

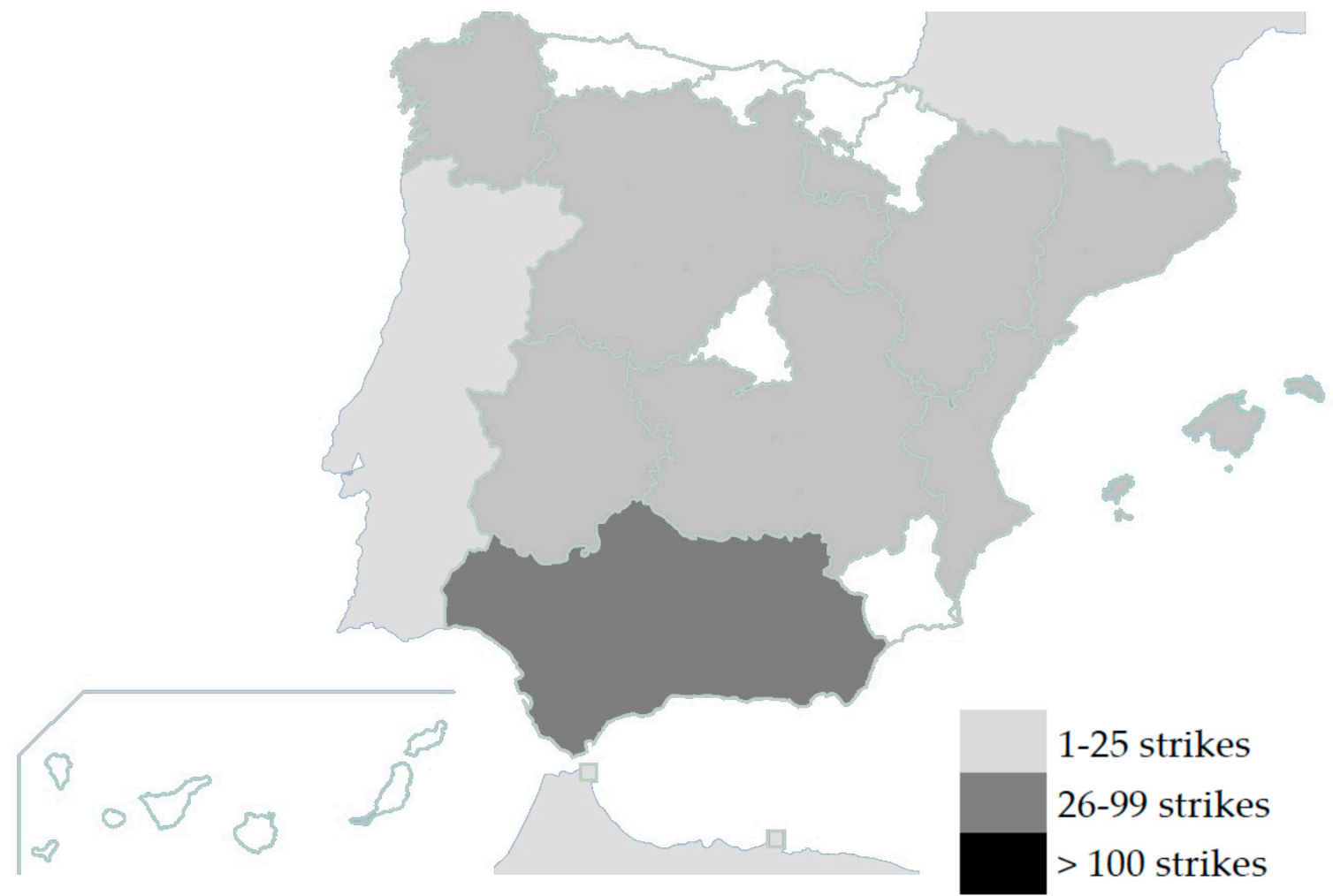

Figure 4. Geographic distribution of the strikes in forestry and agricultural industries by Spanish region, 1932. Data source: Boletín del Ministerio de Trabajo y Previsión Social (1934). Own elaboration. 


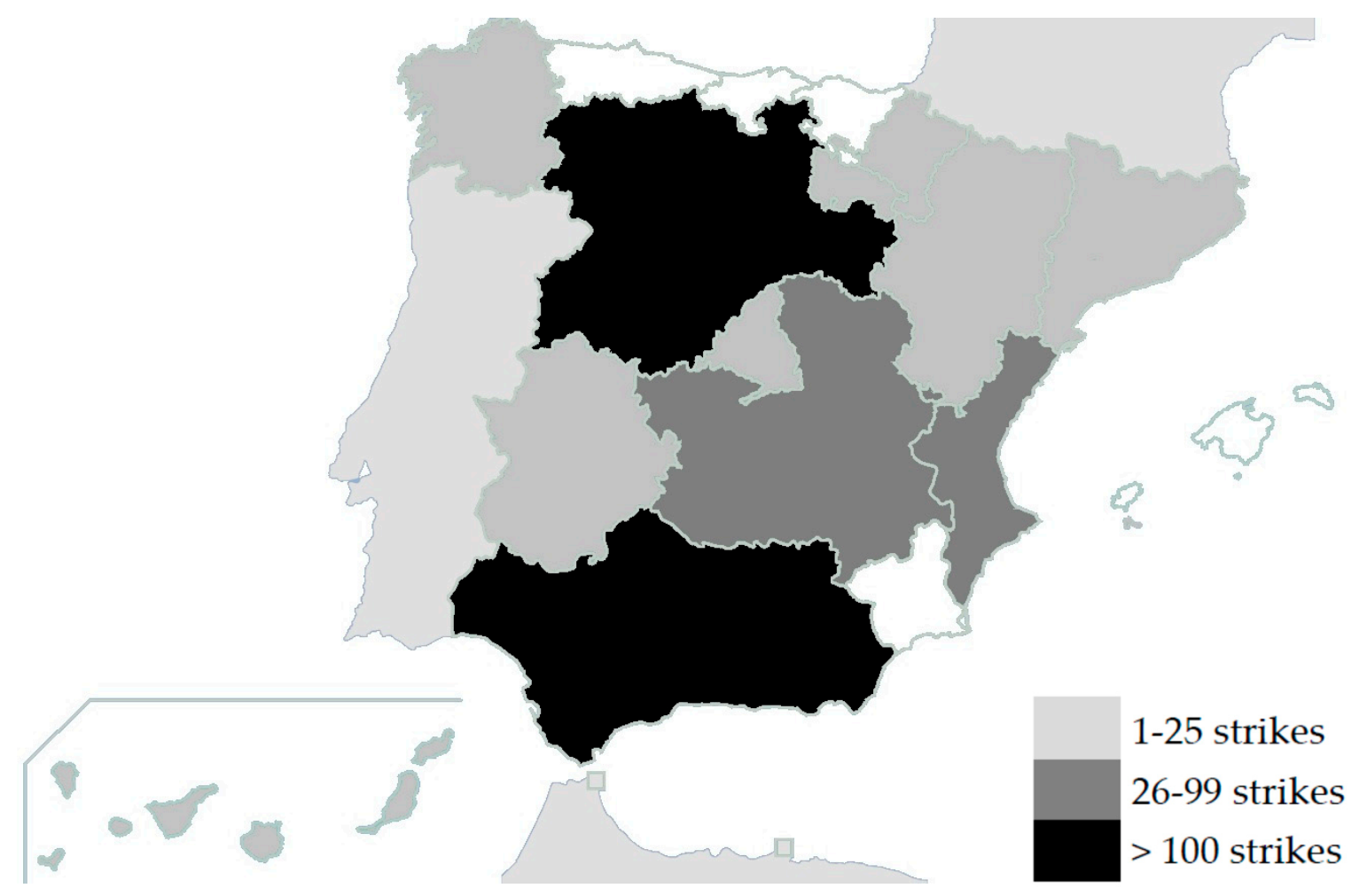

Figure 5. Geographic distribution of the strikes in forestry and agricultural industries by Spanish region, 1933. Data source: Boletín del Ministerio de Trabajo y Previsión Social (1935). Own elaboration.

Figures 3 and 4 show that, at the beginning of the Second Republic, the level of rural unrest was fairly low in the majority of Spanish regions, except for Castilla-León and Galicia in 1931, and Andalusia in 1932, which had a medium level of unrest. This trend was interrupted in 1933, as we can see in Figure 5, when there was a significant increase in the unrest. In this sense, the case of Andalusia stands out, with the progressive increase experienced by rural unrest in this region during the first biennium, from a low level of conflict in 1931, to an average level in 1932, and a high level in 1933. This evolution could be partly related, to the vicissitudes experienced by the Agrarian Reform Law in the region since September 1932, together with the impact of the new agricultural labour legislation and the control of the local governments exercised by the left-wing parties [16,28,34].

The arrival of the Second Republic coincided with the exacerbation of the deflationary and depressive trends of the agricultural and international economic crisis of the 1930s. The crisis affected the main exporting sectors and the traditional Castilian cereal agriculture sector for different reasons. The latter saw its prices plummet as a consequence of the excellent wheat harvests of 1932 and 1934. The drop in prices of the principal agricultural export products-olive oil and oranges-together with the increase in wages and main production costs (reduction in the length of the working day, machinery...), led to a loss in the profitability of many farms. This situation did not only affect the medium and large owners, but also an unknown number of small owners and lessees who, increasingly more oriented towards a capitalist agriculture, frequently turned to the labour market to hire day labourers who were essential for working in the fields [29]. The combination of these adverse circumstances gave rise to an unstable situation in agriculture and in agricultural labour relations which, in turn, led to an increase in strike conflicts, particularly in 1933, as we can see in Figure 5.

It is within this context, together with the reality of the landowners, that we should consider the grievance action taken from 1931 by the agricultural unions whose membership grew with the significant increase in farm workers, on the whole salaried, during the republican period. The joint action of the socialist and anarchist agricultural unions and the adoption of collective bargaining to establish working conditions, led to a conflictive situation in agriculture, as it implied the loss of control 
of the labour market by the farm owners. We should also add that the passing of different decrees drawn up by the Ministry of Employment and Social Welfare, directed by the socialist Francisco Largo Caballero during the first biennium, did not mitigate the model, but rather exacerbated it, despite being measures that sought to resolve unemployment, such as the Law of Municipal Boundaries or the Law of Forced Labour. The former obliged landowners to preferably hire labourers of the town who were registered in job banks, rather than those who were not, women or outsiders. Meanwhile, under the Law of Forced Labour, the landowners were obliged to farm their land following "traditional land uses", and its articles include a threat, to those who breach its provisions, with the lease of their properties to the legally constituted groups of agricultural workers. [35,36].

Figure 5 also shows that, at the end of the first two years of the Republic, labour unrest in the Spanish countryside was prominent and more varied that traditionally reported in the specialised bibliography, in accordance with the extraordinary diversity that characterised Spanish agriculture of that time [37,38]. Judging from the results obtained, the unrest depended largely on the degree of implementation and mobilisation of the agricultural unions in certain regions, the unemployment rates and the resistance of the landowners to the agricultural reform of 1932, and the application of the employment legislation before day labouring and collective bargaining. The data in Figure 5 show that Castilla-La Mancha, with a predominance of extensive farming carried out by day labourers; and eastern Valencia, with a highly profitable intensive farming by small landowners and lessees, displayed medium levels of unrest (between 26 and 99 strikes). In any case, the data enable us to confirm that Andalusia, principally in the provinces where latifundios were predominant around the Guadalquivir valley with a high incidence of landless day labourers, and Castilla-León with a predominant cereal monoculture and an abundance of medium and small mainly poor farms, were the two Spanish regions that experienced the highest level of agricultural unrest in 1933.

What factors can explain this increase in labour unrest in the aforementioned agricultural regions? In the case of Andalusia, the specialised historiography indicates that the hunger for land in the latifundio areas, together with the terrible living conditions of the masses of day labourers and the fears of the large owners of the agricultural reform, constituted a breeding ground for unrest $[20,28,39]$. To this, we should also add the refusal of the landowners to farm their land without using machinery or to fulfil the employment regulations dictated by the Mixed Juries of Rural Labour in the collective bargaining. This bargaining, on the other hand, did not guarantee the absence of conflicts [40]. In the case of Castilla-León, the attempts of the first republican governments to liberate the cereal market, subject to strict intervention since 1915, coincided fatally in time with a devaluation of grain in international markets and with the excellent wheat harvests of 1932 and 1934, which generated a fall in income. Also to be taken into account is the discontent of the large and small landowners, fuelled by the agricultural reform and the application of many regulations regarding working conditions which implied wage increases for day labourers, leading to a large number of conflicts in the cereal-growing areas of Castilla-León around 1933 [41].

In the territory of Castilla-La Mancha, the international protectionism hindered Manchego wine exports and slowed down the increase in wine prices. The problems of the agricultural sector could not be resolved with the evolution of olive growing either, which was experiencing an increase in rural unemployment. The stagnation of oil prices led to a fall in the profitability per hectare between 1931 and 1935. Therefore, the negative evolution of agricultural prices and the increase in unemployment aggravated the social unrest in this region of inland Spain [42]. Meanwhile, during the third quarter of 1933, the eastern part of Spain was ranked fourth in terms of the number of unemployed after western Andalusia, Extremadura and Castilla-La Mancha [43]. Specifically, in Valencia, the majority of the strikes and conflicts were related to the application of the new labour laws, particularly with respect to the placement of agricultural workers, at a time when the employment crisis was serious, due to the fall in the exports of the rice and orange growing areas, increasing rural unemployment slightly.

In terms of the percentage distribution of the agricultural strikes by Spanish region, it may be observed that in the first two-year period of the Republic, some territories had high percentages of 
rural unrest, others had an intermediate level and, finally, certain territories had low percentages of unrest. By 1933, as we can see in Figure A2 of Appendix A, the regional ranking had become clear: among the regions with the highest percentage of agricultural unrest, and for specific reasons in each case, which have been partly discussed, there was a peripheral region and a central region: Andalusia (with an increase from 14\% of the agricultural conflicts in 1931 to $42.5 \%$ in 1933) and Castilla-León (from $15.9 \%$ to $28.7 \%$, respectively). Together, the unrest in the two regions increased from $29.9 \%$ of agricultural strikes to $71.3 \%$. The territories with an intermediate position included Castilla-La Mancha and Valencia. Together, these two regions accounted for $15.6 \%$ of the agricultural strikes in 1933. Finally, among the regions with the lowest percentage of rural unrest were Aragon, Extremadura, the Canary Islands, Madrid, and all of the small and medium-sized owners and lessees in Galicia, La Rioja, Catalonia and Navarre. Together, they represented 13.1\% (Figure A2 of Appendix A). Of these, the case of Extremadura is particularly interesting. In this region there was a predominance of large estates and landless "yunteros" (peasants who used a pair of oxen or mules to work the land). The objectives of the Agrarian Reform Law of 1932 included the implementation of different mechanisms for assigning land and agricultural resources. To do so, it was decided that different solutions be applied to satisfy the "hunger for land" of the day labourers and poorest peasants. One of the proposed mechanisms was the expropriation of unfarmed or poorly farmed land. Attempts were made to palliate the slowness of applying the Agrarian Reform Law through a complementary measure, which was the Decree of Crop Intensification of 22 October 1932, which enabled the temporary occupation of estates which were no longer leased or farmed and were only used for cattle in the southern half of Spain, as was the case of Extremadura. The decree affected around 1,500 estates in nine provinces (approximately 125,000 hectares) and hired around 40,000 families, the majority in Extremadura, whose members were unemployed [44,45]. For the case of Extremadura, particularly in the Province of Badajoz, thanks to the Decree of Intensification, the level of unrest in the region decreased considerably during the winter of 1933 to 1934 ([46], p. 60).

\subsubsection{Second Biennium 1934-1935}

The electoral victory of the centre-right coalition in November 1933 was a key element of the evolution and dynamics of the labour unrest during the second biennium of the Republic, including that of the rural areas. This was basically because it enabled the agricultural employers of many regions to start feeling protected by the presence of a clear anti-reformist parliamentary majority. Supported by the new political scene arising from the elections, the agricultural employers stepped up their actions of resistance and non-compliance with the new republican reformist labour legislation, collective bargaining and the agricultural reform passed during the first biennium. Even so, the strategy of the agricultural employers that was most used from the beginning of 1934 to weaken the challenging capacity of socialist or anarchist agricultural trade unions consisted in the labour discrimination of day labourers who were members of these unions, together with the repeated rejection of collective bargaining and the non-compliance with the labour legislation [12].

The combined use of the above-described strategies enabled the landowners to impose harsh working conditions on the day labourers, such as a reduction in wages, the lengthening of the working day or recurring to piecework, which was despised by the salaried workers. The frustration of the expectations of the labourers and farm workers began to increase from the end of 1933 until the spring of 1934, a context which explains the anarchist rebellion of December 1933 (which was preceded by those carried out in January 1932 and 1933). Furthermore, the organisational structure constructed by the socialist agricultural trade unionism when the first biennium was dismantled, which translated into the persecution of the principal union leaders of each municipality, which, after the failure of the peasant strike of June 1934, culminated in the mass imprisonment of the union representatives of the National Federation of Land Workers (FNTT) and the closure of the Casas del Pueblo (Houses of the People). After the failure of the peasant strike of 1934 and the revolutionary strike of October of the same year, the challenging action of the agricultural unions diminished. In addition, the left-wing mayors lost 
control of the local governments and were replaced with management committees, presided by local authorities related to the interests of the large agricultural employers or members of the conservative republican parties [24]. This political union repression can be observed in Figures 6 and 7. It was reflected by a substantial decrease in the number of strikes and rural unrest throughout the whole of the Spanish countryside. In absolute terms, the number of strikes in forestry and agricultural industries fell from 435 in 1933 to 93 in 1934, and dropped to just 23 in 1935, according to the data compiled in the Ministry of Employment Gazettes. No region exceeded the low level of unrest; and in some regions, no strikes at all were registered in 1935. The evidence is not only related to the political and union repression imposed in 1934-1935, but also to the agrarian counter-reform, passed in 1935 (which, de facto, caused the definitive freezing of the 1932 reform) and the problems encountered by the many Mixed Juries of Rural Work in negotiating the new bases for work.

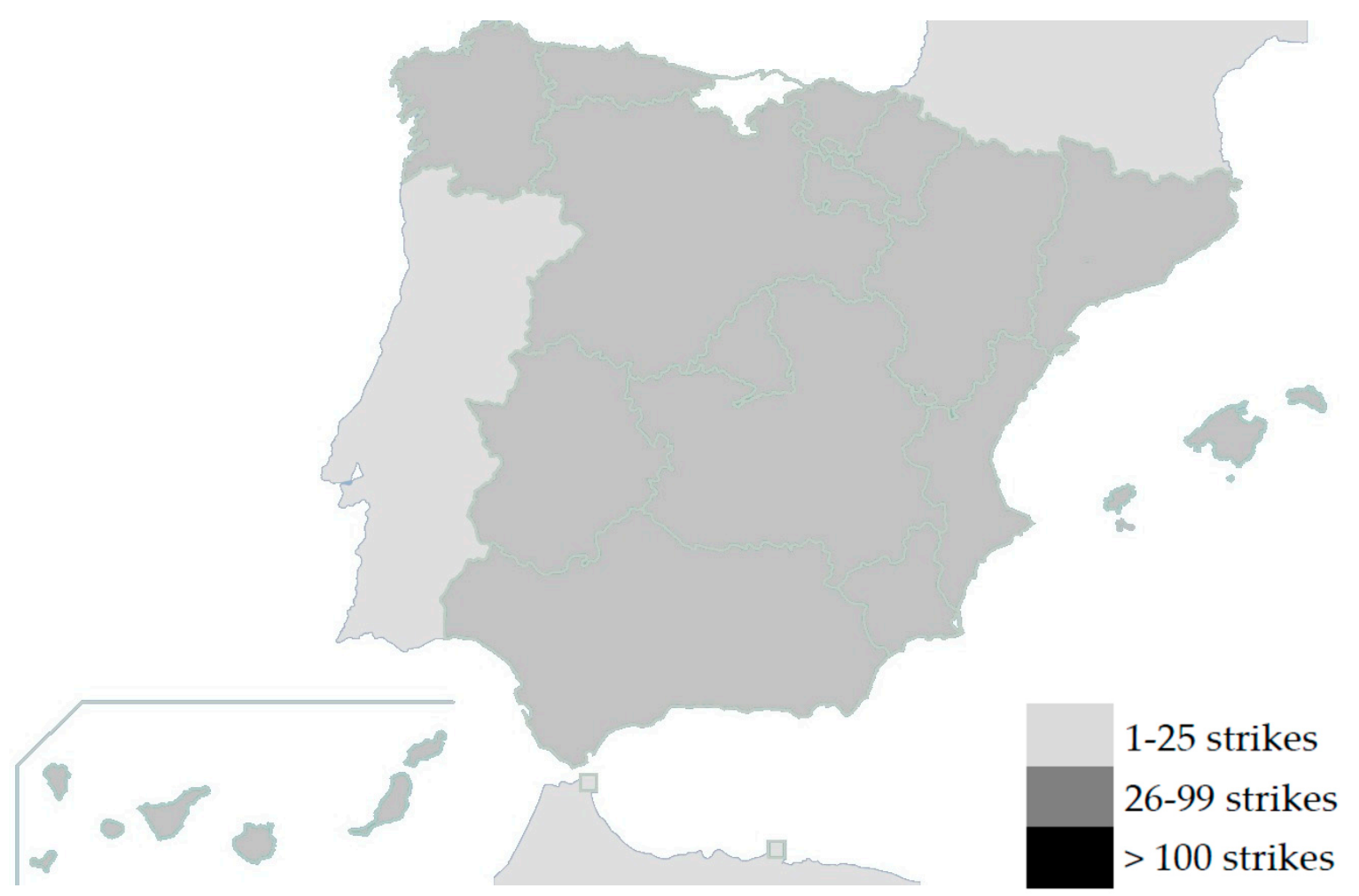

Figure 6. Geographic distribution of the strikes in forestry and agricultural industries by Spanish region, 1934. Data source: Boletín del Ministerio de Trabajo y Previsión Social (1936). Own elaboration. 


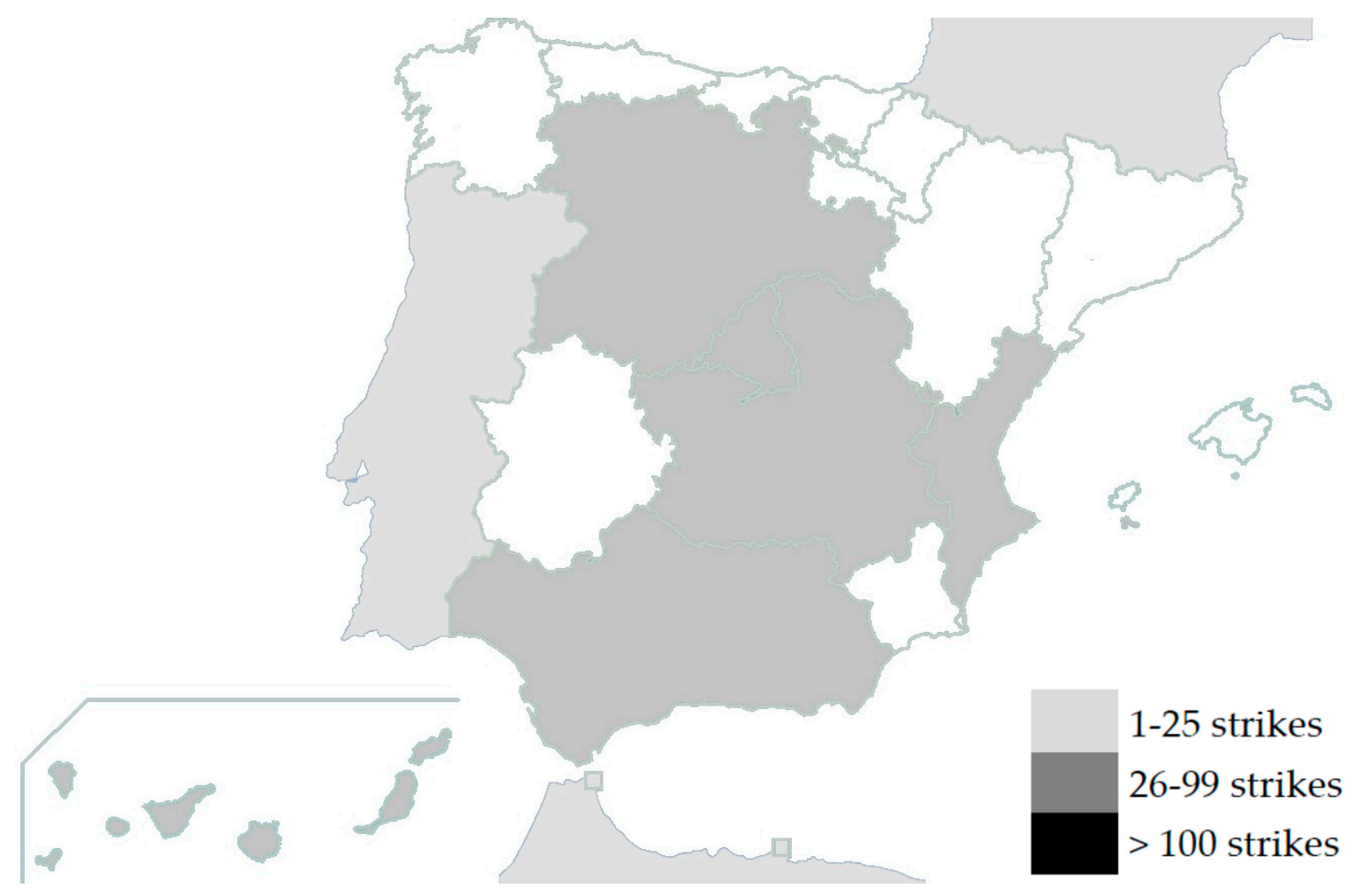

Figure 7. Geographic distribution of the strikes in forestry and agricultural industries by Spanish region, 1935. Data source: Boletín del Ministerio de Trabajo y Previsión Social (1935). Own elaboration.

\subsubsection{Period of the Popular Front, February-July 1936}

The election results of February 1936 returned the power to the left-wing political organisations. The data drawn from the Ministry of Employment Gazettes indicate an increase in the number of strikes during the first half of 1936 with respect to those registered during the period 1934-1935 (Figure 2). We can also observe this in Figure 8. Compared with 1935, the map shows that the majority of Spanish regions registered an upturn in the unrest in the spring of 1936, highlighting the cases of Andalusia and Castilla-León, whose levels of unrest increased from low to medium. According to the studies consulted, from the beginning of 1936, the majority of the Andalusian provinces recorded an unrest oriented towards mitigating agricultural unemployment, which increased during the spring months of that year. Many local unions of the FNTT implemented numerous strike actions to demand the application of the advantageous working conditions which had been in force during 1932 and 1933 and included significant wage increases. During these months, at the same time, the left-wing parties recovered their control of the local governments which had been in the hands of the conservative coalition throughout 1934. In practice, there was a greater representation of the working class in the new local governments, re-balancing the power relations throughout the countryside, with a peasant class seeking compensation for "the many humiliations that it had been subjected to by the agricultural employers during the immediately preceding period" [34,47]. Nevertheless, the response of the landowners was immediate: they demanded the freedom to choose the day labourers for farm work and the right to disregard those registered in the municipal job banks [48]. Meanwhile, between the months of March and May, many of the regional union leaders demanded the urgent execution of the agricultural reform [20,49]. After months of delay, on the 16 April 1936, and under the orders of the new Minister of Agriculture, Mariano Ruiz-Funes, the conservative Agricultural Reform Law of 1935 was revoked, and the one approved in September 1932 by the centre-left republican government was restored [50]. Within the new political context, the implementation of the new reform, conceived as a "bottom-up agricultural reform", was not going to be placed in the hands of the engineers of the Agricultural Reform Institute (IRA), but those of the people's and union initiative that promoted the 
invasion of estates in March 1936, captained by the FNTT ([16], p. 76). This new balance of power in the Spanish countryside was not going to be tolerated by the agricultural employers, who, together with other anti-republican groups opposing the republican reformist policy, recurred to violence to eliminate it and return to the traditional status quo [51].

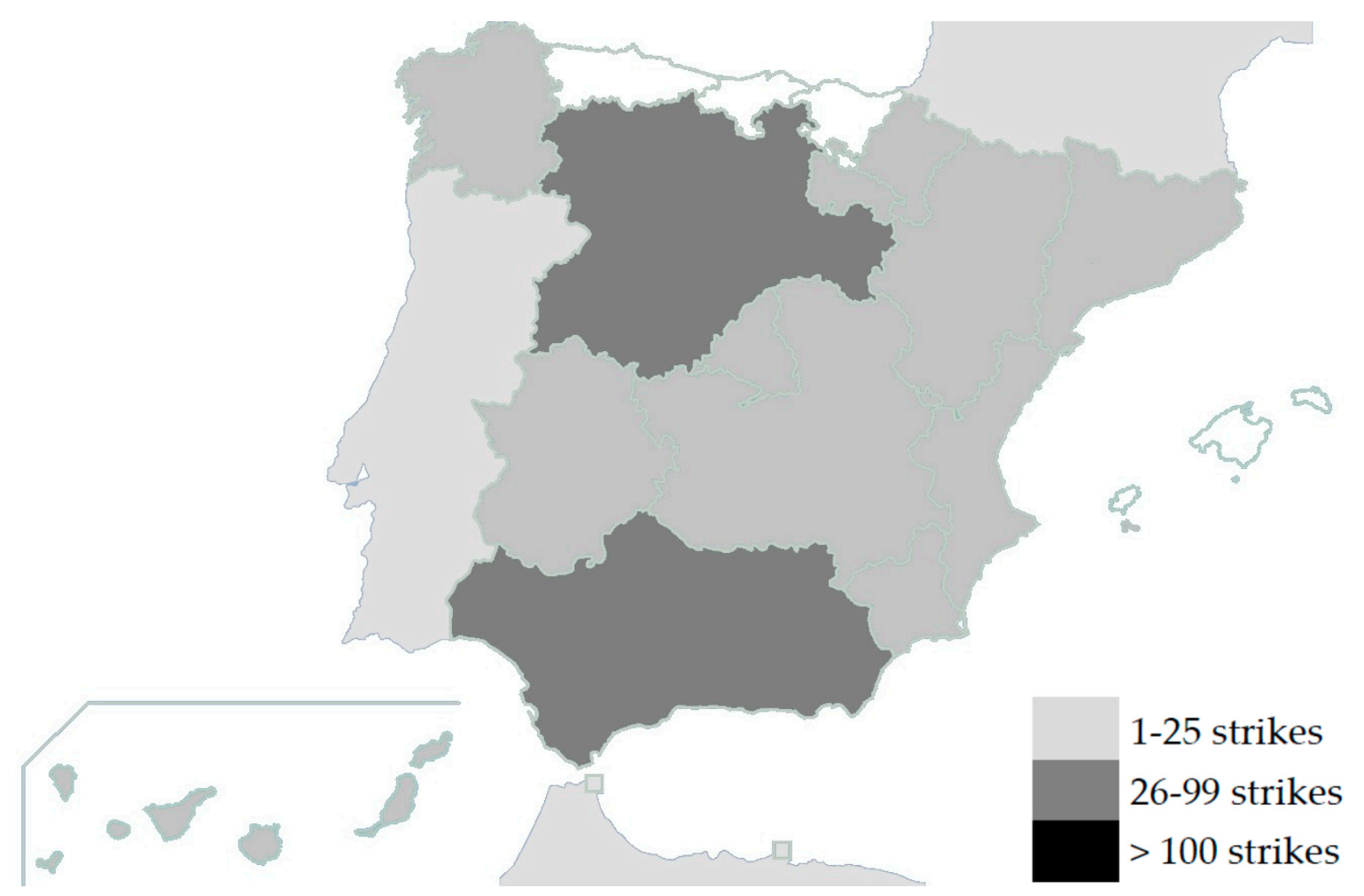

Figure 8. Geographic distribution of the strikes in forestry and agricultural industries by Spanish region, February-July 1936. Data source: Boletín del Ministerio de Trabajo y Previsión Social (1936). Own elaboration.

\subsection{Rural Unrest on a Provincial Scale}

\subsubsection{First Biennium 1931-1933}

What happened in the Spanish provinces? Was the regional distribution of agricultural unrest mirrored on the provincial level? Figures 9-11 present the results of the geographic distribution of the number of strikes in forestry and agricultural industries and their intensity by Spanish province in the years 1931, 1932 and 1933. Overall, the provincial data reveal that the period of the first biennium offered a highly diverse panorama, probably due to the fact that rural unrest greatly depended on the degree of implementation and mobilisation of the agricultural unions, the impact of the employment crises, the unemployment rates, and the weight agriculture in the respective provincial economies, one of the sectors most affected by the international economic depression. Similarly to the regional scale, it can be observed that 1933 was the year in which the unrest peaked, at least until the upturn in the spring of 1936. This is no coincidence. Together with the political and legislative explanatory factors, the increase in rural unrest in some provinces was also the result of the resistance of the large landowners to accept the agricultural reform of 1932 [20,39,52]. 


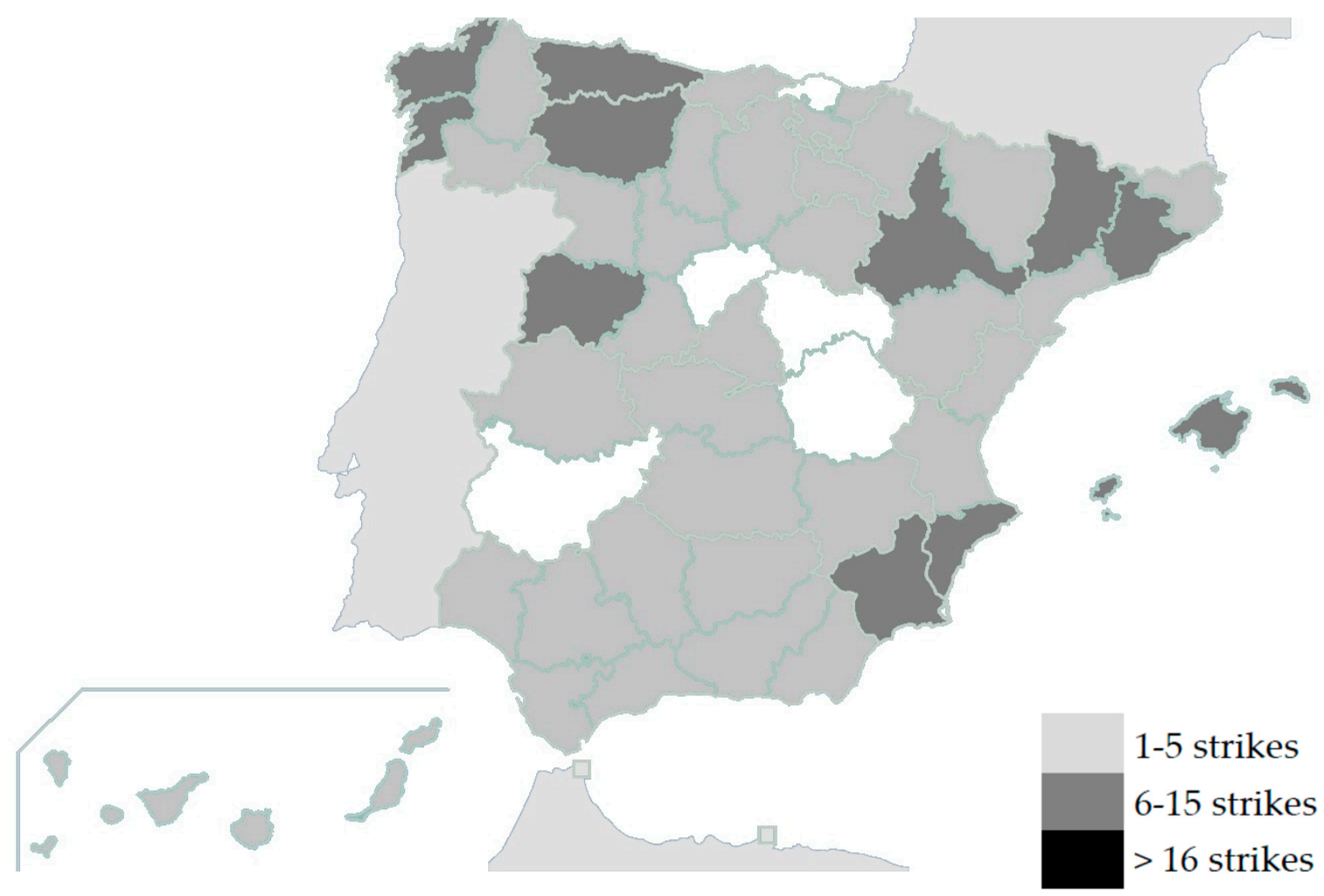

Figure 9. Geographic distribution of the strikes in forestry and agricultural industries by Spanish province, 1931. Data source: Anuario Estadístico de España (1931) and ([30], p. 192-193). Own elaboration.

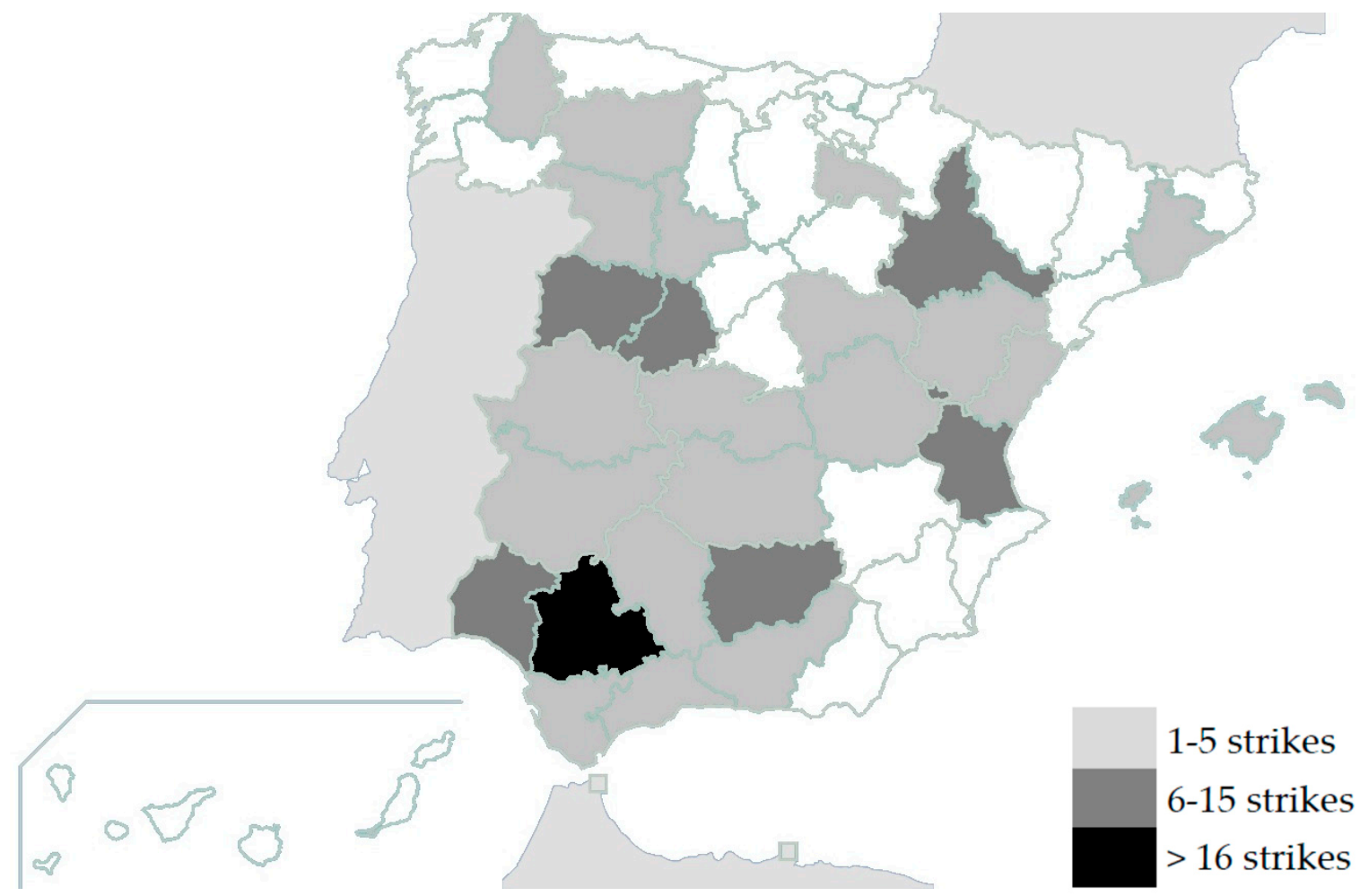

Figure 10. Geographic distribution of the strikes in forestry and agricultural industries by Spanish province, 1932. Data source: Boletín del Ministerio de Trabajo y Previsión Social (1934). Own elaboration. 


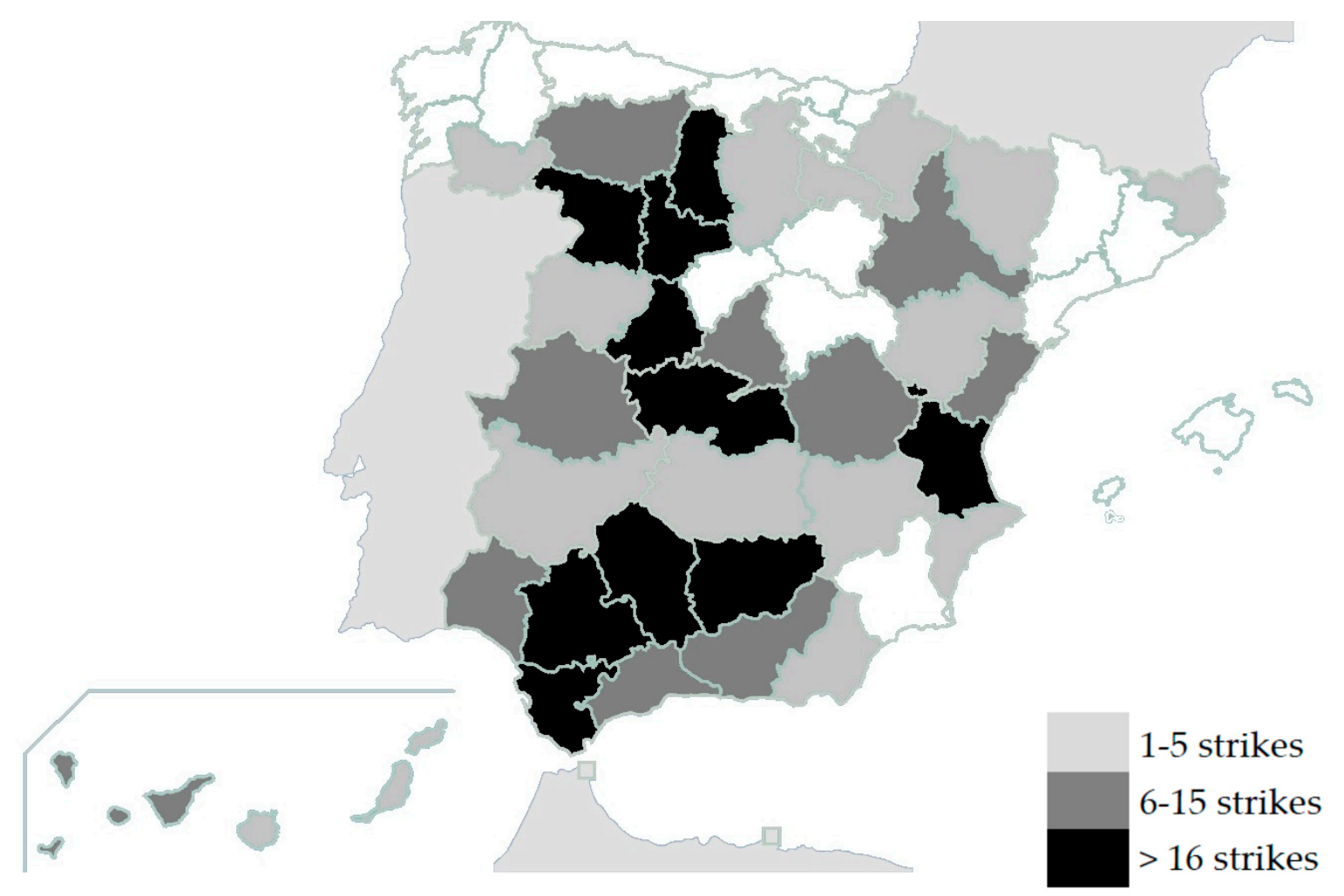

Figure 11. Geographic distribution of the strikes in forestry and agricultural industries by Spanish province, 1933. Data source: Boletín del Ministerio de Trabajo y Previsión Social (1935). Own elaboration.

During the years 1931-1932, the majority of Spanish provinces had a low level of unrest (between 1 and 5 strike), except for the provinces of Salamanca and Zaragoza, which, during this time, recorded a medium level of unrest (Figures 9 and 10). In the case of Zaragoza, for example, the unrest during these years was caused by the agricultural employers' rejection of collective bargaining, and the increase in wages approved by the Mixed Juries at a time when, according to the landowners, agricultural products were depreciating [53]. The repudiation of the republican agricultural legislation was also observed in other provinces in the country, such as Seville [54], which, according to our data, in 1932, was the Spanish province with the highest level of unrest (Figure 10). However, it is remarkable that, in some very rural provinces with a strong union presence, the agricultural strikes were scarce in the first biennium, as we can see in the cases of Ciudad Real or Albacete (Figures 9 and 10). According to the studies consulted, collective conciliation was preferred, whereby the workers obtained moderate advantages from the Mixed Juries [55]. According to the data that we have collected, this agreement probably explains that, in 1932, the province of Albacete did not record any strikes in the forestry and agreement industries (Figure 10). The low level of unrest in other typically latifundist provinces is also noteworthy, for example, the Province of Badajoz, which can largely be explained by the benefits gained from the Decree of Crop Intensification during the first biennium among the "yunteros" of Extremadura [46]. Nevertheless, even in these provinces, in 1933, we can clearly observe the continuous increase in union demand and the resistance of the employers, pressured by the wage increases already granted and the increase in the demands for them to eliminate machinery, piecework and any other procedure which, in the opinion of these workers' organisations, aggravated unemployment [42,56].

The unrest also intensified in rural Valencia in 1933, which had been a relatively calm province in this respect in the preceding years (Figures 9-11). The international economic crisis of 1929 dealt a hard blow to the agriculture of Valencia, which gave rise to a severe contraction of orange and rice exports and an increase in agricultural unemployment [43]. We can find another example in Andalusia, where the FNTT of the region was progressively promoting partial stoppages and general strikes in 1933 in several provinces, particularly in June, coinciding with the cereal harvest. The cases of Seville, 
Malaga and Cadiz are particularly noteworthy [28]. In these Andalusian provinces, as in others of the geographic areas of the latifundios, the unease of the landowners towards the implementation of the agricultural reform was also a cause of unrest in 1933. The cases of Cordoba, Toledo or Badajoz, with a medium-high level of unrest, illustrate this (Figure 11) [39,49]. And although it is true that the large landowners were the most threatened by the agricultural reform, there are sufficient examples of the damage suffered by the small landowners and lessees caused by the republican agricultural legislation designed solely, as they themselves admitted, to benefit the day labourers.

The historiography on the rural unrest during the Second Republic reveals that the increase in costs, the difficulties created by the corporativism of the Mixed Juries and the strikes did not affect the large owners any more than the small ones. And it was the smaller landowners who struggled the most to cope with the increase in their costs and, most of all, to hire labour without using machinery and based on the working conditions agreed by collective bargaining $[29,36]$. This sparked irritation in these medium-sized rural areas which, in many cases, had received the Republic with enthusiasm and found themselves, however, trapped in a difficult economic situation, with an increase in production costs and growing unrest. The case of the province of Jaén is illustrative: according to our data, Jaén was the Spanish province that experienced the greatest increase in rural unrest at the end of the first biennium of the republic. At this time, this province of Upper Andalusia experienced a growing unrest which increased the number of strikes from three recorded in 1931 in the Ministry of Employment Gazettes to 60 in 1933 (Figures 9 and 11). In percentage terms, the increase was equally significant, growing from $1.8 \%$ in 1930 to $13.8 \%$ in 1933 (Figure A3 of Appendix A).

The explosion of unrest in the Jaén countryside was the result of the confluence of two main factors; first, the economic crisis that affected the provincial olive oil producing industry, which, due to the fall in demand, suffered falling prices and the loss of profitability of many farms; and second, the implementation of the collective bargaining for working conditions, which contributed to increasing the wages paid to the day labourers and the application of measures which sought to mitigate agricultural unrest, such as the Law of Municipal Boundaries or the Law of Forced Labour [29], whose principal novelties introduced to the agricultural labour framework have been described in the previous section on regional unrest.

Contrary to the little real impact of the agricultural reform in many territories until March 1936, [20], these two republican laws altered the former ways of hiring labour, subverting the everyday life of the majority of Spanish provinces which, until then, had allowed the agricultural employers to control the labour market and prevent peasant strikes. In the case of Jaén, for example, the Law of Municipal Boundaries harmed the small owners and lessees as it prevented many of them from periodically travelling to other municipalities that required labour, as they had been doing for years, in order to find work in olive and cereal harvesting. With these stints in other territories, many modest farmers of Upper Andalusia complemented their incomes derived from their small farms. Hence their insistence that the aforementioned law be repealed [36]. The Law of Forced Labour, which obliged landowners to farm their land following the "traditional land uses", subjecting day labourers to situations of forced labour, in practice, prohibited some of the resources available to farmers to mitigate the fall in profits, such as the mechanisation of certain tasks or the use of piecework [36]. The rigorous application of the two collective bargaining regulations, defended by the mayors and local socialist unions, together with the effects of the economic crisis, gave rise to the spread of strike action among day labourers and agricultural workers, in general, particularly small landowners and tenants, who were most affected by the increase in costs and the strike action of the day labourers. Faced with this situation, many of them began to express their rejection of the agricultural workers' unions and the presence of socialist politicians in many local councils, which was manifested in the elections of 1933. In this year, the centre-right candidates were victorious in the province as a whole, with one of their main social supports being the unhappy small landowners and farm tenants. The evidence has been interpreted as an electoral punishment of the socialist party for the economic damage caused 
by the republican labour legislation, particularly the aforementioned Municipal and Forced Labour Law $[29,36]$.

The case of Jaén is similar to that of other provinces in Castilla-León (Figures 11 and A3 of Appendix), as indicated by the historiography [41]. Generally speaking, in the regions where latifundios were not predominant, with an abundance of small landowners and lessees, which was the case of Upper Andalusia or Eastern Spain, it was the difficulties in applying the new agricultural labour legislation, together with the belligerent attitude of the agricultural employers towards collective bargaining of working conditions and the increase in unemployment that basically explain the determinants of the rural unrest $[35,43]$.

\subsubsection{Second Biennium 1934-1935}

During the second biennium of the republic, in the same way as the regional level, the political change derived from the formation of a centre-right coalition government and the removal of many left-wing local councils was an influential factor in the incidence of labour unrest. This can be observed in Figures 12 and 13, which present the geographic distribution of the number of strikes in forestry and agricultural industries and their intensity by Spanish province for the years 1934-1935.

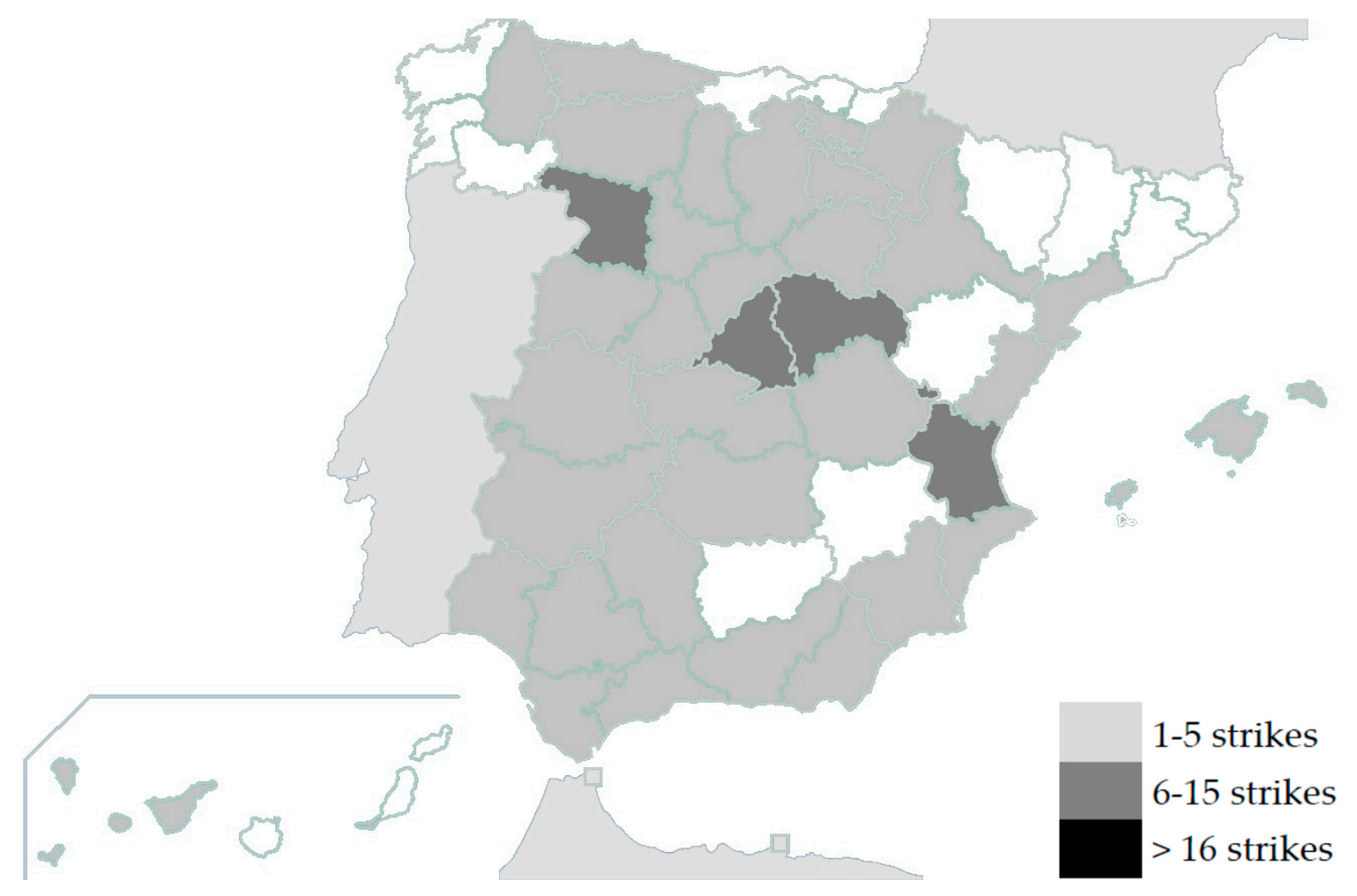

Figure 12. Geographic distribution of the strikes in forestry and agricultural industries by Spanish province, 1934. Data source: Boletín del Ministerio de Trabajo y Previsión Social (1936). Own elaboration.

Compared with 1933, Figures 12 and 13 show that during the years of the second biennium, the unrest in the Spanish countryside clearly decreased. At least several reasons would explain this. First, the failed agricultural general strike of June 1934, which led to the break-up of the FNTT across most of the national territory. Second, the subsequent repression of the workers movement; and, of course, the removal of the local governments presided by left-wing mayors. Without unions and without the control of the local councils, the principal objective of the agricultural employer became the neutralisation of the effects of the labour laws, and the paralysation of the agricultural reform. In the first case, the control or abolition of the Mixed Juries from Rural Labour was essential. In the second case, the parliamentary repeal of the laws was needed to invalidate them, which was brought 
about with the approval of the Agrarian Reform Law, better known as "the agrarian counter-reform", of 1 August 1935 ([20], p.8, 17). During the first months of 1934, numerous complaints were received from agricultural towns, denouncing that the republican labour legislation was being boycotted or that the ordinary functioning of the Mixed Juries was in decline, with many of them virtually paralysed due to the blockade being implemented by the employer representatives. In the middle of this year, the majority of these juries were overwhelmed by the accumulation of workers' claims with respect to wages that had not been paid by agricultural employers [39]. Protests were made by the local unions of the FNTT about the low wages paid and the long working hours in almost all of the Andalusian provinces, those in Extremadura, some of the Castilla-León provinces, those in Eastern Spain and in Castilla-la-Mancha.

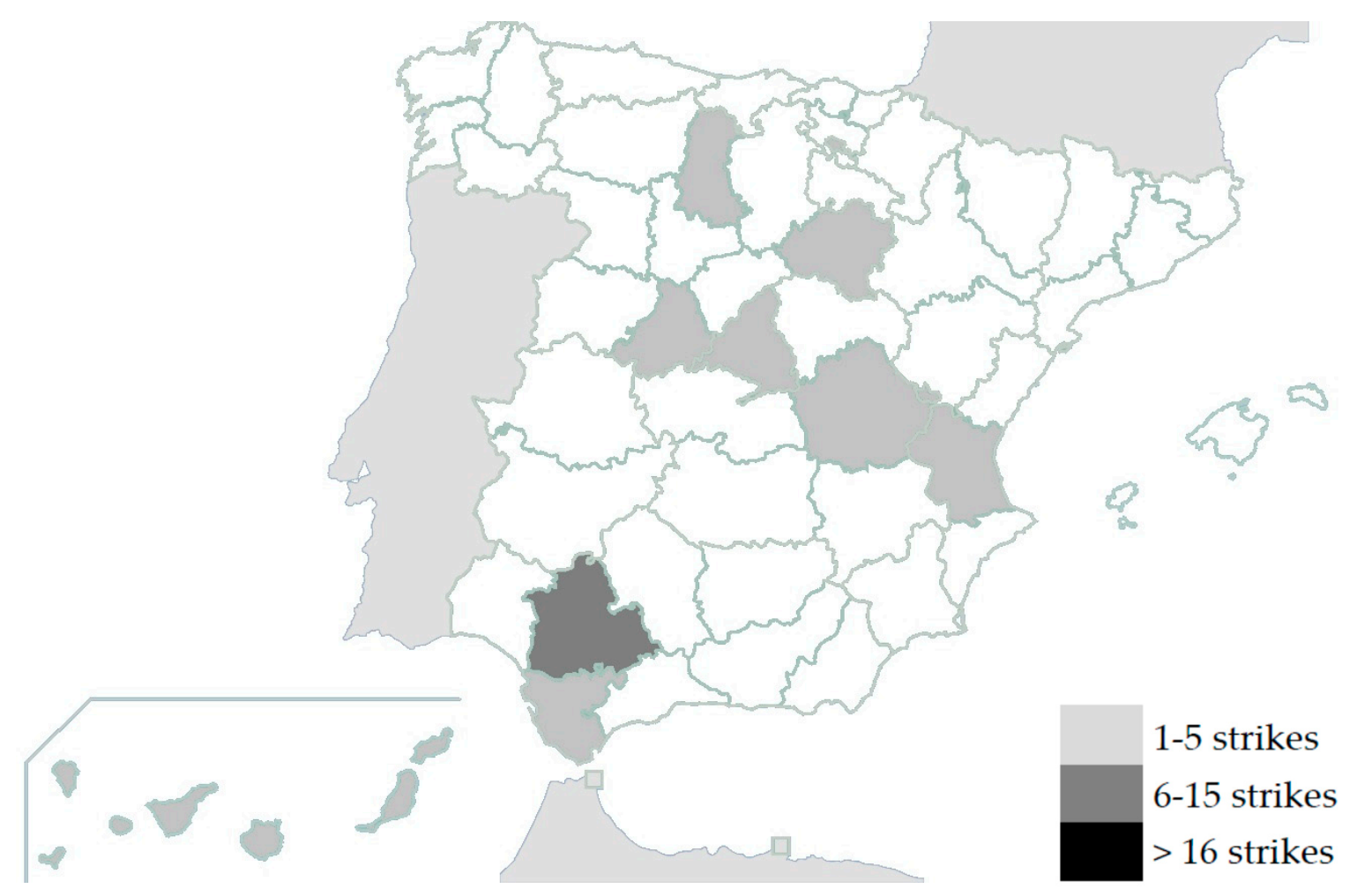

Figure 13. Geographic distribution of the strikes in forestry and agricultural industries by Spanish province, 1935. Data source: Boletín del Ministerio de Trabajo y Previsión Social (1935). Own elaboration.

Within this new economic context, the capacity of the agricultural trade unions to challenge the laws diminished throughout 1934 and 1935. There are several indicators that show this, according to the Ministry of Employment Gazettes. On the one hand, the number of strikes in the forestry and agricultural industries decreased on a provincial level between 1933 and 1935: from the 435 recorded in 1933, they fell to 93 in 1934 and to 23 in 1935. In this latter year, for example, only ten of the fifty provinces analysed experienced some kind of conflict. The rest did not record any strikes (Figure 13). On the other hand, and in relation to the above, the intensity of the unrest decreased. The high level of unrest recorded in 1933 diminished to a low level of unrest in 1934, and was practically non-existent in 1935 (Figures 12 and 13). The case of the province of Jaén, again, illustrates this point: in 1933, this province of Upper Andalusia led the provincial ranking in terms of the number of strikes in the forestry and agricultural industries (60), but, during the years of the second biennium, it did not record any at all. This fact is attributable to the removal of the left-wing local governments, the political and ideological repression, the dismantling of the day labourer unions and the repeal of many of the reformist labour laws of the first biennium. In fact, after the victory of the conservative coalition in November 1933, the agricultural employers began an attack against the left-wing local governments. 
The objective was to recover the control over the local councils which were essentially administrative bodies with regulatory functions with respect to labour relations [34]. The evidence can be extrapolated to other provinces of rural Spain. In the case of Badajoz, for example, and based on the study of the functioning and effectiveness of the Rural Policy Commission of the small town of Santa Marta, the boundaries of the republican reformism is illustrated, and it indicates how the landowners were more concerned about not losing "the control of the labour market" and the elasticity of their supply than the increase in productivity ([57], p. 126).

\subsubsection{Period of the Popular Front, January-July 1936}

In contrast to the years of the second biennium, the Spanish countryside experienced a relative increase in rural unrest during the spring of 1936 (Figure 14). In the province of Seville, for example, which had a high level of unrest, the occupation of estates was recorded. Groups of day labourers from many towns in which there were socialist unions moved to estates, in order to undertake the corresponding work. At the end of the day, the workers sought out the employers to demand them the payment of their wages. The employers association of Seville protested to the provincial authorities about this situation [58]. In the province of Granada, like in other regions in the centre and south of the peninsula, the towns with agricultural unions belonging to the FNTT once again became the scene of protests and strike action, which sought compliance with the work agreements and labour legislation of the first biennium. They also called for wages to be increased through the application of the working conditions corresponding to the years 1932 and 1933, as they considered these wages to be higher than those stipulated in the conditions in force of the year 1934. Even so, the most frequent type of labour conflict consisted in the imposition of agricultural labourers on certain estates without the authorisation of the owners. The scale of the invasions of estates gave rise to frequent protests by the employers, which led to the intervention of the civil governor $[39,42,48]$.

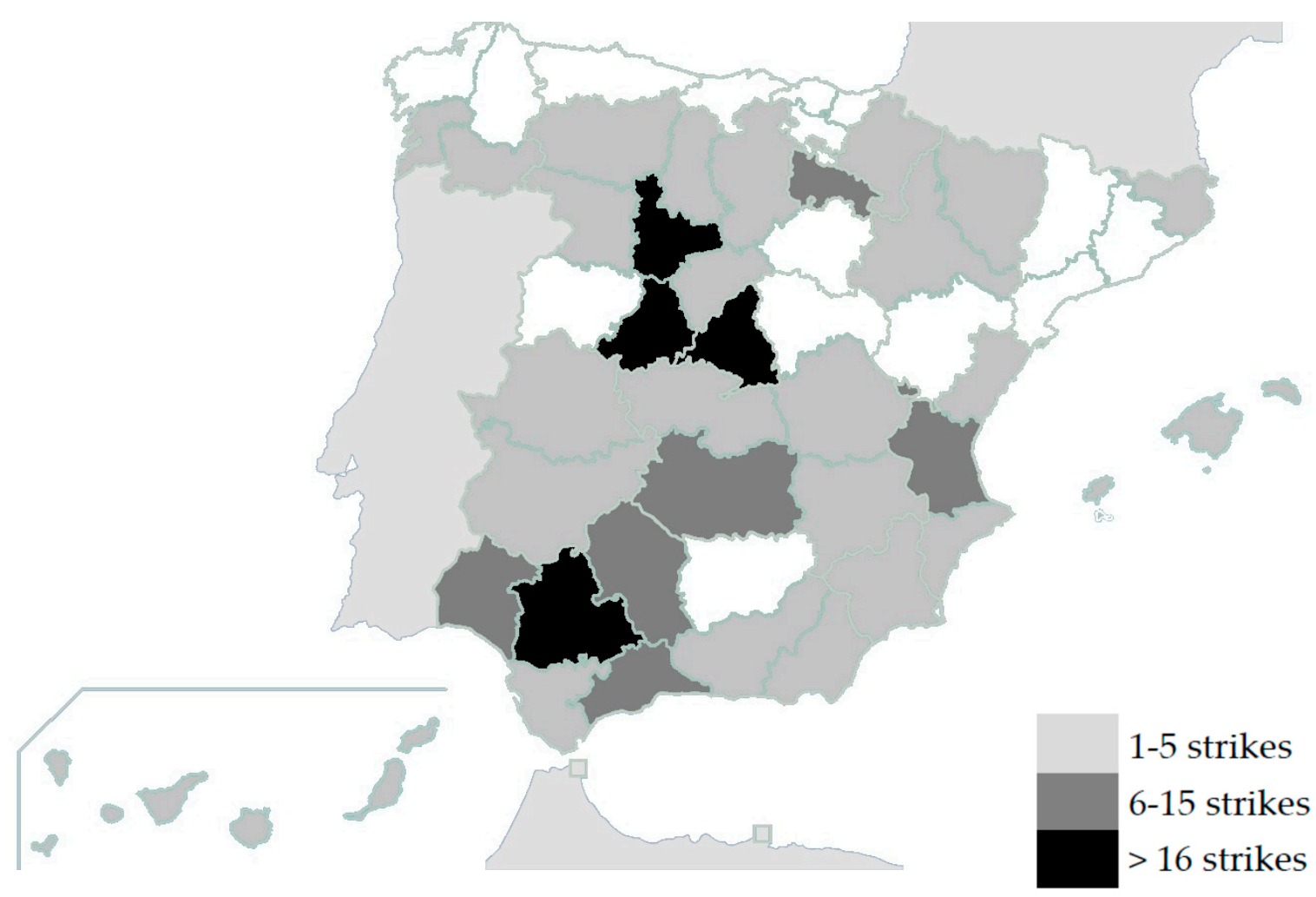

Figure 14. Geographic distribution of the strikes in forestry and agricultural industries by Spanish province, February-July 1936. Data source: Boletín del Ministerio de Trabajo y Previsión Social (1936). Own elaboration. 
According to the studies carried out, during the spring of 1936, the agricultural conflicts taking place in many Spanish provinces where there was a high incidence of day labourers in the workforce experienced a qualitative change with respect to the procedures used. These included threats to the employers, the invasion of estates, demands of day labourers who were unemployed and mass divisions. Not to mention, the provincial leaders of the unions demanding the rapid execution of the agricultural reform [48]. The triumph of the Popular Front in 1936 and the subsequent political change had immediate effects on the rural environment: the figures show that between February and July of this year, at least 110,921 peasants were placed in 572,055 hectares of land ([20], p. 432). In fact, the victory of the Popular Front and the return of the representatives of rural workers to the local governments began a new phase, whereby the unanimous request of the rural working classes was the demand for the collectivisation of the land and a transformation of the existing relations of production [34,47]. The new catalogue of protests and unrest sometimes gave rise to serious confrontations which resulted in a high number of deaths among the law enforcement forces and, also, the day labourers; violent confrontations which, in some way, foretold the tragedy that was to unfold during the civil war of 1936-1939. The events occurring in Yeste, in the province of Albacete, in March 1936, are an example of this violence, illustrating that the local scale was the setting, par excellence, of the agricultural conflict ([59], p. 166).

\section{Conclusions}

Like other neighbouring countries, throughout the interwar period, Spain experienced an accelerated crisis of the liberal system, which was accompanied by a deterioration of the political, economic and social spheres. The turbulent years of the Second Spanish Republic (1931-1936) constitute a good example of this. The republican regime, which, through moderate reforms, sought to transform and modernise the traditional political, economic and social structures of the country, clashed with the progressive discontent of the middle classes and employers who were hit hard by the economic crisis of the 1930s and, even more, by the advocacy strength of the unions and the diffusion of strike action. From a labour history and historic geography perspective, this article analyses the evolution and geographic distribution of the rural unrest during the period of the Spanish Second Republic. It is a methodology that, based on the territorial use of strike data, allows us to measure the incidence that rural policies and labour relations had in the different Spanish regions and provinces of that time during the republican period. The strikes classified in the forestry and agricultural industries, counted on a provincial level in the Ministry of Employment and Social Welfare Gazettes, constitute the main source for the study.

For a long time, part of the historiography regarding the republican regime associated the majority of the unrest in the Spanish countryside with the problem of agriculture based on latifundios. The hunger for land, the terrible living and working conditions of the masses of day labourers, and the fears of the large landowners with respect to the announcement of a new agricultural reform, constituted the breeding ground for highly explosive situations. In the other types of Spanish agriculture, it was maintained that the unrest was weaker than that in those parts where latifundios were predominant. However, the results obtained in this article reveal that the agricultural strikes and the rural unrest were more widespread than originally believed during the five-year period of the republic. Although it is probable that the conflicts were not comparable with the social tension experienced in the areas of the latifundios in Lower Andalusia, Extremadura and Castilla-La Mancha, our data reveal that rural Spain, in all its diversity, was affected by the labour unrest. The false impression that there were no problems in the areas where latifundismo was not practiced cannot be upheld, as, for example in the case of Valencia, a province without any extreme unrest, but with constant conflicts arising due to the impact of the economic crisis, the increase in rural unemployment and the non-compliance by employers of the agreed working conditions. In other territories with a predominance of small landowners and lessees, such as Ávila and Valladolid in Castilla-León, the difficult economic situation, the increase in production costs and collective bargaining of the working 
conditions constituted the causes of persistent conflicts. Taken as a whole, the results also show that the evolution of the agricultural strikes were subject to cycles conditioned by the political, economic and labour policy conjuncture; so, the strikes increased during the first two years of the Republic, particularly in 1933. They decreased in 1934-1935 after the failure of the peasant strike of June 1934, the removal of left-wing local governments and union repression, and increased again during the months of the Popular Front (February to June 1936).

In conclusion, this article reveals that the rural unrest during the Spanish Second Republic was more diverse and rich in nuances than originally thought, consistent with the extraordinary diversity that characterised Spanish agriculture of that time, which was due not only to the impact of the proposed agricultural reform, but also to economic and institutional factors of the labour market and the attitudes and behaviours of employers and workers in the rural environment.

Author Contributions: Authors have collaborated on each stage of the research. In this sense, J.P. and C.G.M. have worked on the location of the study sources and the elaboration of the materials used (maps and figures). Likewise, they have jointly written the article, interpreting the results achieved.

Funding: This research was funded by the following projects with reference: S55_17R (Department of Innovation, Research and Universities of the Regional Government of Aragon and the European Regional Development Fund (ERDF); E030-01 (complementary research aids ACI-University of Murcia); 19247/PI/14 (Séneca Foundation-Agency of Science and Technology of the Region of Murcia); and ECO2015-65582 (Spanish Ministry of the Economy and Competitiveness, MINECO).

Acknowledgments: The authors would like to express their gratitude to the technical personal of the Library of the Ministry of Employment (Madrid) for their help in carrying out this research and would like to also express their thanks to the screening Committee of the SEHA Congress (held in June 2018) for selecting the paper that originally provided the basis for this article for its publication in the Special Issue "Selected Papers from the 2nd International Conference on Transitions in Agriculture and Rural Society. The Global Challenges of Rural History". An advanced version of this study was presented in the Economic History Seminar of the University of Zaragoza, for which we are grateful for the comments received in addition to the observations of the three referees.

Conflicts of Interest: The authors declare no conflict of interest.

\section{Appendix A}

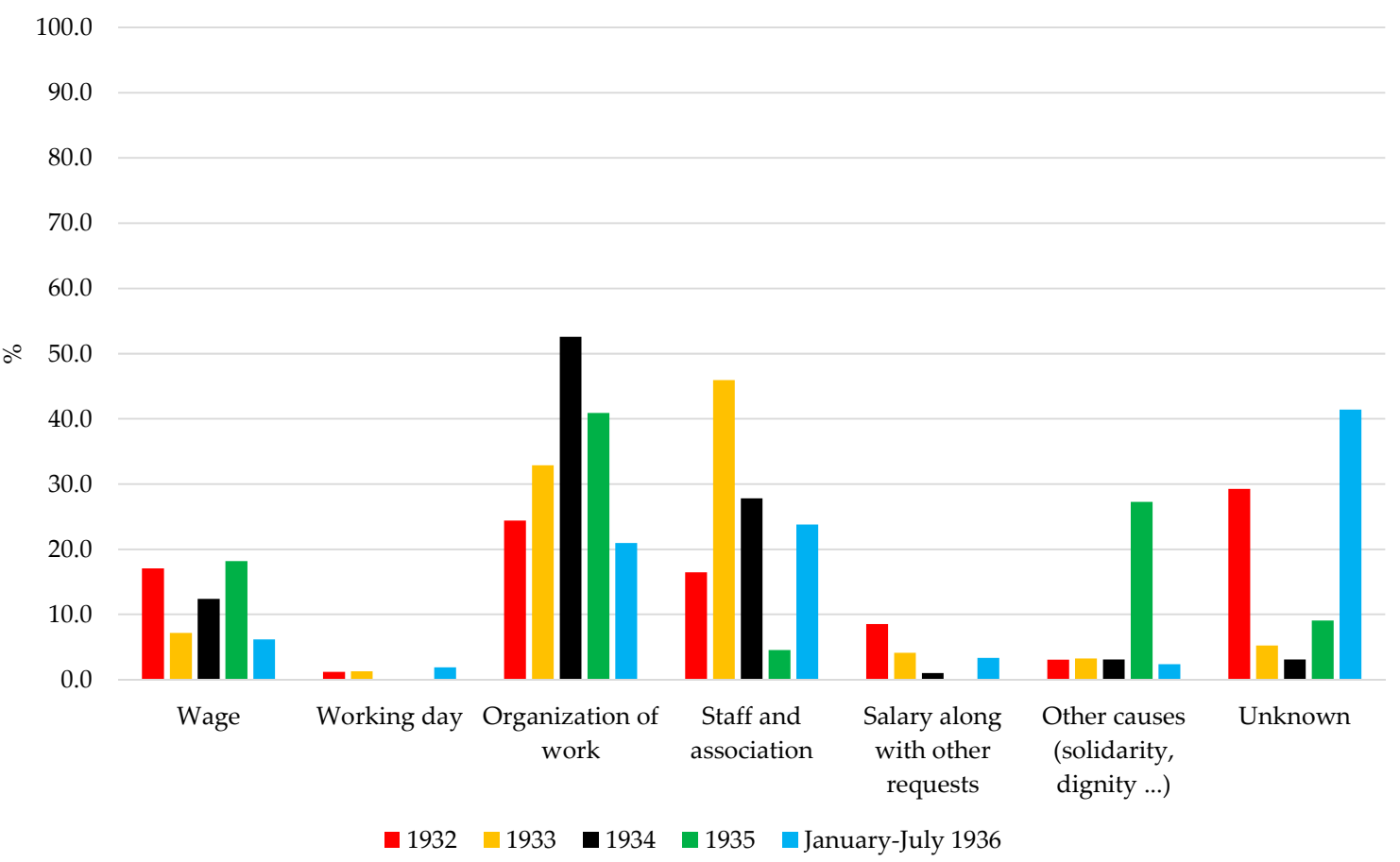

Figure A1. Causes of the strikes in forestry and agricultural industries in Spain, 1932-July 1936. Data source: Boletines del Ministerio de Trabajo y Previsión Social (1932-July 1936). Own elaboration. 


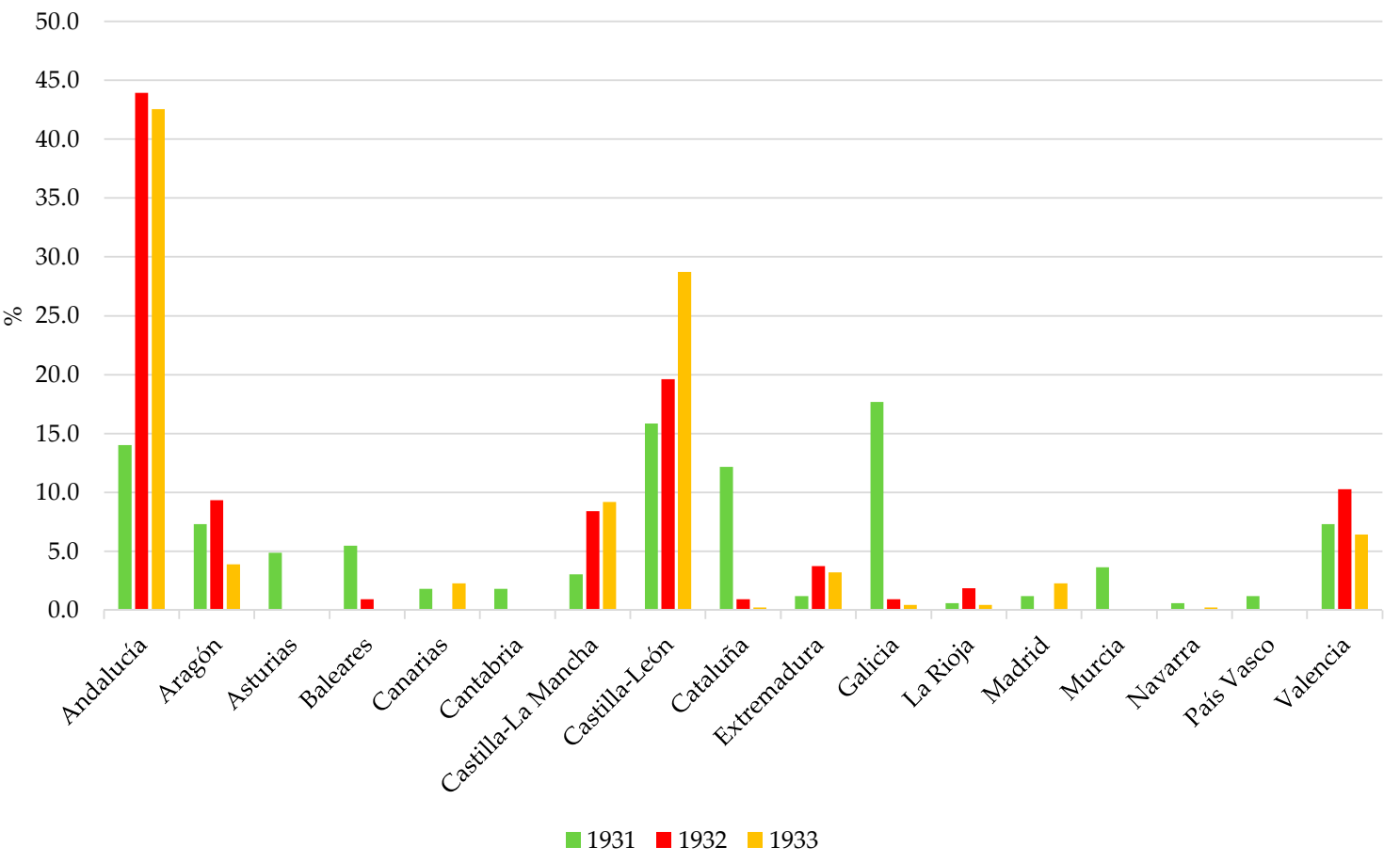

Figure A2. Geographic distribution of the strikes in forestry and agricultural industries by Spanish region, 1931-1933 (in \%). Data source: Anuario Estadístico de España (1931), ([23], p. 192-193) and Boletines del Ministerio de Trabajo y Previsión Social (1934-1935). Own elaboration.

25.0

20.0

15.0

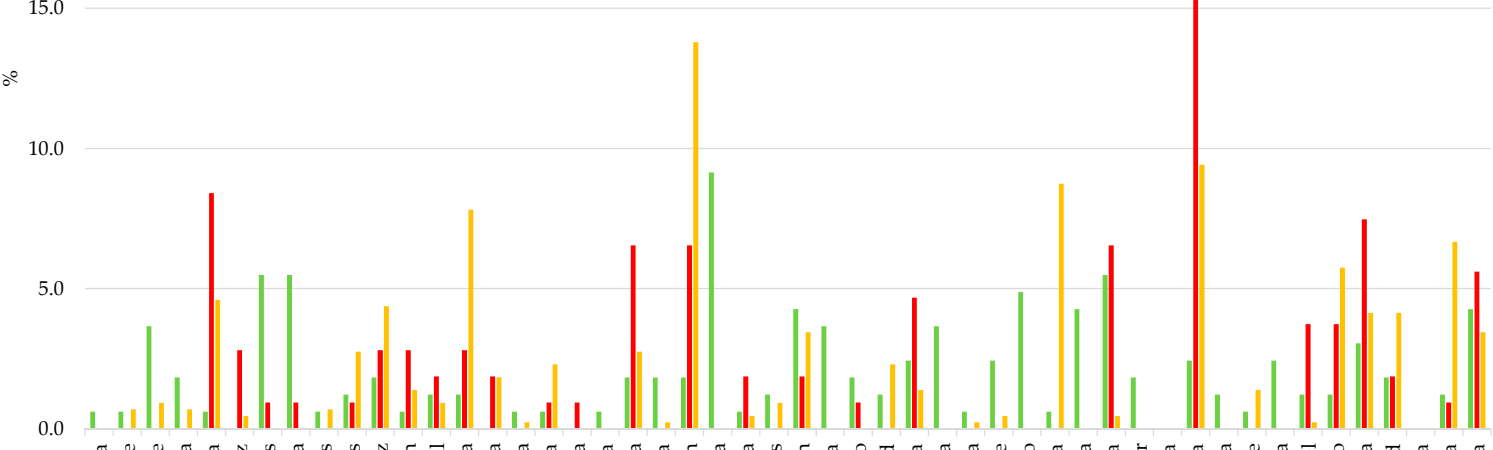

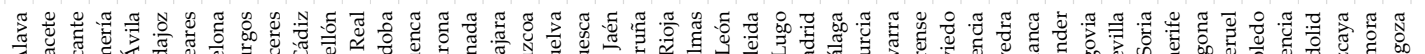

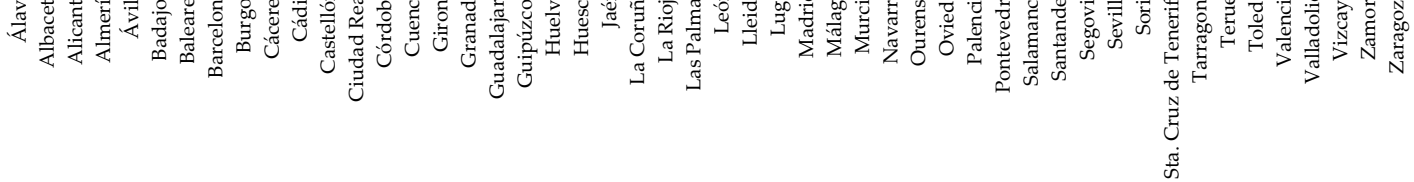

$\square 1931 \square 1932 \square 1933$

Figure A3. Geographic distribution of the strikes in forestry and agricultural industries by Spanish province, 1931-1933 (in \%). Data source: Anuario Estadístico de España (1931), ([23], p. 192-193) and Boletines del Ministerio de Trabajo y Previsión Social (1934-1935). Own elaboration. 


\section{References}

1. Mosse, G.L. De la Grande Guerre au Totalitarisme. La Brutalisation des Sociétés Européennes; Hachette: Paris, France, 1999.

2. Kershaw, I. Descenso a Los Infiernos; Crítica: Barcelona, Spain, 2016.

3. González Martínez, C.; Souto Kustrín, S. Por el Estado/contra el Estado: Las milicias políticas en el primer tercio del siglo XX, In Las Milicias del rey de España. Sociedad, Política e Identidad en las Monarquías Ibéricas; Ruiz Ibáñez, J.J., Ed.; Fondo de Cultura Económica (FCE): Madrid, Spain, 2009; pp. 481-515.

4. Luebbert, G.M. Liberalismo, Fascismo o Socialdemocracia. Clases Sociales y Orígenes Políticos de Los Regímenes de la Europa de Entreguerras; Prensas Universitarias de Zaragoza: Zaragoza, Spain, 1997.

5. Casanova, J. Europa Contra Europa (1914-1945); Crítica: Barcelona, Spain, 2011.

6. Del Rey, F.; Álvarez Tardío, M. Políticas del Odio. Violencia y Crisis en las Democracias de Entreguerras; Tecnos: Madrid, Spain, 2017.

7. González Calleja, E.; Cobo Romero, F.; Martínez Rus, A.; Sánchez Pérez, F. La Segunda República Española; Pasado \& Presente: Barcelona, Spain, 2015.

8. Comín, F. La gran depresión internacional y la Segunda República. In Crisis Económicas en España, 1300-2012. Lecciones de la Historia; Comín, F., Hernández, M., Eds.; Alianza Editorial: Madrid, Spain, 2013; pp. 133-164.

9. Aróstegui, J. Introducción: España República de trabajadores. In La República de los Trabajadores. La Segunda República y el Mundo del Trabajo; Aróstegui, J., Ed.; Fundación Francisco Largo Caballero: Madrid, Spain, 2006; pp. 50-61.

10. Álvarez Tardío, A.; Del Rey, F. El laberinto Republicano. La Democracia Española y sus Enemigos (1931-1936); RBA: Barcelona, Spain, 2012.

11. Cabrera, M. La Patronal Ante la II República. Organizaciones y Estrategias, 1931-1936; Siglo XXI: Madrid, Spain, 1983.

12. González Calleja, E. Conflictividad sociolaboral y violencia colectiva en la Segunda República. In La República de los Trabajadores. La Segunda República y el Mundo del Trabajo; Aróstegui, J., Ed.; Fundación Francisco Largo Caballero: Madrid, Spain, 2006; pp. 76-108.

13. Caro Cancela, D. El mundo Campesino en la España de los Años Treinta; Diputación de Cádiz: Cádiz, Spain, 2009.

14. Domenech, J. Rural labour markets and rural conflict in Spain before the Civil War (1931-6). Econ. Hist. Rev. 2013, 66, 86-108. [CrossRef]

15. Domenech, J. Land Tenure Inequality, Harvests, and Rural Conflict: Evidence from Southern Spain during the Second Republic (1931-1934). Soc. Sci. Hist. 2015, 39, 253-286. [CrossRef]

16. Robledo, R. Sobre el fracaso de la Reforma agraria andaluza en la Segunda República. In La Cuestión Agraria en la Historia de Andalucía: Nuevas Perspectivas; González de Molina, M., Ed.; Centro de Estudios Andaluces: Sevilla, Spain, 2014; pp. 61-96.

17. Robledo, R. La reforma agraria en España durante la II República (1931-1939). Rev. Est. Ext. 2015, 71, 19-48.

18. Robledo, R.; González Esteban, A.L. Tierra, trabajo y reforma agraria en la Segunda República española (1931-1936): Algunas consideraciones críticas. Hist. Agra. 2017, 72, 37-78.

19. Brenan, G. El Laberinto Español. Antecedentes Sociales y Políticos de la Guerra Civil; Backlist: Barcelona, Spain, 1962.

20. Malefakis, E. Reforma Agraria y Revolución Campesina en la España del Siglo XX; Ariel: Barcelona, Spain, 1976.

21. Jackson, G. La República Española y la Guerra Civil; Crítica: Barcelona, Spain, 1976.

22. Cobo Romero, F. La cuestión agraria y las luchas campesinas en la II República, 1931-1936. Hisp. Nov. 2013, 11, 270-305.

23. Domenech, J.; Herreros, F. Land reform and peasant revolution. Evidence form 1930s Spain. Exp. Econ. Hist. 2017, 64, 82-103. [CrossRef]

24. Lopéz Martínez, M. Cambio y represión: La conjunción negativa. La destitución de los ayuntamientos republicano-socialistas. Granada, 1933-1936. Rev. Hist. Cont. 1995, 6, 119-144.

25. Macarro Vera, J.M. Socialismo, República y Revolución en Andalucía (1931-1936); Universidad de Sevilla: Sevilla, Spain, 2000.

26. Del Rey Reguillo, F. Paisanos en Lucha. Exclusión Política Violencia en la Segunda República Española; Biblioteca Nueva: Madrid, Spain, 2011. 
27. Del Rey Reguillo, F. Palabras Como Puños. La Intransigencia Política en la Segunda República Española; Tecnos: Madrid, Spain, 2011.

28. Montañés, E. Economía agrícola y conflicto en Cádiz durante la Segunda República. In El mundo Campesino en la España de los Años Treinta; Caro Cancela, D., Ed.; Diputación de Cádiz: Cádiz, Spain, 2009; pp. 155-191.

29. Cobo Romero, F. De Campesinos a Electores. Modernización Agraria en Andalucía, Politización Campesina y Derechización de los Pequeños Propietarios y Arrendatarios. El Caso de la Provincia de Jaén, 1931-1936; Biblioteca Nueva: Madrid, Spain, 2003.

30. Alcaide, J. Evolución Económica de las Regiones y Provincias Españolas en el Siglo XX; Fundación BBVA: Bilbao, Spain, 2003.

31. Rodríguez Labandeira, J. El trabajo Rural en España (1876-1936); Editorial Anthropos-Ministerio de Agricultura, Pesca y Alimentación: Madrid, Spain, 1991.

32. Silvestre, J. Los determinantes de la protesta obrera en España, 1905-1935: Ciclo económico, marco político y organización sindical. Rev. Hist. Ind. 2003, 24, 51-79.

33. Soto Carmona, A. El ciclo largo de conflictividad social en España (1868-1986). Rev. Tra. Seg. Soc. 1991, 2, 157-179.

34. Cobo Romero, F. El control campesino y jornalero de los ayuntamientos de la Alta Andalucía durante la crisis de los años treinta (1931-1939). Hispania 1999, 201, 75-96.

35. González Martínez, C. Relaciones laborales en Murcia durante la experiencia republicana: Actitudes y conflictos. Hist. Soc. 1999, 33, 73-95.

36. Cobo Romero, F. El voto campesino contra la II República. La derechización de los pequeños propietarios y arrendatarios agrícolas jiennenses, 1931-1936. Hist. Soc. 2000, 37, 119-142.

37. Gallego, D. Pautas regionales de cambio técnico en el sector agrario español (1900-1930). Cua Ara Econ. 1993, 3, 241-276.

38. Simpson, J. La agricultura Española (1765-1965): La Larga Siesta; Alianza Editorial: Madrid, Spain, 1997.

39. Pérez de Yruela, M. La Conflictividad Campesina en la Provincia de Córdoba, 1931-1936; Servicio de Publicaciones Agrarias-Ministerio de Agricultura: Madrid, Spain, 1979.

40. Montañés, E. Crisis agrícola y reformismo republicano: La instauración de la negociación colectiva en la campiña andaluza, 1931-1933. Est. Reg. 1997, 49, 133-160.

41. Hermida Revillas, C. Economía Agraria y Agitaciones Campesinas en Castilla La Vieja y León: 1900-1936. Ph.D. Thesis, Universidad Complutense de Madrid, Madrid, Spain, 1989.

42. Ladrón de Guevara, M.P. La Esperanza Republicana. Reforma Agraria y Conflicto Campesino en la Provincia de Ciudad Real (1931-1939); Diputación Provincial de Ciudad Real: Ciudad Real, Spain, 1993.

43. Bosch, A. La Segunda República y la Guerra Civil: Conflicto rural y colectivización. In De la Revolución Liberal a la Democracia Parlamentaria: Valencia (1808-1975); Preston, P., Saz, I., Eds.; Biblioteca Nueva-Universidad de Valencia: Madrid, Spain, 2001; pp. 237-253.

44. Gil Pechorromán, J. La Segunda República. Esperanzas y Frustraciones; Historia 16: Madrid, Spain, 1997.

45. Simpson, J.; Carmona, J. Too many workers or not enough land? The experience of land reform in Spain during the 1930s. Hist. Agra 2017, 72, 37-68.

46. Riesco Roche, S. La cuestión yuntera en Extremadura durante la II República. Hist. Soc. 2009, 65, 41-60.

47. Caro Cancela, D. La primavera de 1936 en Andalucía: Conflictividad social y violencia política. In Andalucía y la Guerra Civil. Estudios y Perspectivas; Álvarez Rey, L., Ed.; Universidad de Sevilla: Sevilla, Spain, 2006; pp. 11-31.

48. López Martínez, M. Orden Público y Luchas Agrarias en Andalucía. Granada, 1931-1936; Editorial Libertarias: Madrid, Spain, 1995.

49. Riesco Roche, S. La reforma Agraria y Los Orígenes de la Guerra Civil. Cuestión Yuntera y Radicalización Patronal en la Provincia de Cáceres (1931-1940); Biblioteca Nueva: Madrid, Spain, 2006.

50. Gracia Arce, B. Trayectoria Política e Intelectual de Mariano Ruiz-Funes. República y Exilio; Universidad de Murcia: Murcia, Spain, 2014.

51. Espinosa Maestre, F. La Primavera del Frente Popular. Los Campesinos de Badajoz y el Origen de la Guerra Civil (Marzo-Julio de 1936); Crítica: Barcelona, Spain, 2007.

52. Sígler, F. Propiedad de la tierra, reforma agraria y asentamientos campesinos. In El Mundo Campesino en la España de los Años Treinta; Caro Cancela, D., Ed.; Diputación de Cádiz: Cádiz, Spain, 2009; pp. 209-232. 
53. Germán, L. Aragón en la República. Estructura Económica y Comportamiento Político; Institución “Fernando el Católico": Zaragoza, Spain, 1984.

54. Florencio Puntas, A. Patronal y sindicatos ante la legislación agraria de la II República: Sevilla (1931-1933). Hist. Cont. 1988, 1, 123-140.

55. Oliver Olmo, P. Control y Negociación. Los Jurados Mixtos de Trabajo en las Relaciones Laborales Republicanas en la Provincia de Albacete (1931-1936); Instituto de Estudios Albacetenses: Albacete, Spain, 1996.

56. Ortiz Heras, M. Violencia Política en la II República y el Primer Franquismo. Albacete, 1936-1950; Siglo XXI: Madrid, Spain, 1996.

57. Riesco Roche, S.; Rodríguez, F.J. Policía rural y mercados de trabajo agrario en la Segunda República: El caso de Santa Marta (Badajoz), 1931-1936. Hist. Agra 2016, 70, 101-130.

58. Pascual Cevallos, F. Luchas Agrarias en Sevilla Durante la Segunda República; Diputación Provincial de Sevilla: Sevilla, Spain, 1983.

59. González de Molina, M. Los socialistas españoles y la cuestión agraria. In La ESPAÑA rural, Siglos XIX y XX. Aspectos Políticos, Sociales y Culturales; Ortega López, T.M., Cobo Romero, F., Eds.; Editorial Comares: Granada, Spain; pp. 155-192.

(C) 2018 by the authors. Licensee MDPI, Basel, Switzerland. This article is an open access article distributed under the terms and conditions of the Creative Commons Attribution (CC BY) license (http:/ / creativecommons.org/licenses/by/4.0/). 